\title{
Clonal conversion of B lymphoid leukemia reveals cross-lineage transfer of malignant states
}

\author{
Rajesh Somasundaram, ${ }^{1}$ Josefine Åhsberg, ${ }_{1}^{1}$ Kazuki Okuyama, ${ }^{1}$ Jonas Ungerbäck, ${ }^{1}$ Henrik Lilljebjörn, ${ }^{2}$ \\ Thoas Fioretos, ${ }^{2}$ Tobias Strid, ${ }^{1}$ and Mikael Sigvardsson ${ }^{1,3}$ \\ ${ }^{1}$ Department of Clinical and Experimental Medicine, Experimental Hematopoiesis Unit, Faculty of Health Sciences, Linköping \\ University, 58183 Linkoping, Sweden; ${ }^{2}$ Department of Laboratory Medicine, Division of Clinical Genetics, Lund University, 22184 \\ Lund, Sweden; ${ }^{3}$ Division of Molecular Hematology Lund University, 22184 Lund, Sweden
}

Even though leukemia is considered to be confined to one specific hematopoietic cell type, cases of acute leukemia of ambiguous lineage and patients relapsing in phenotypically altered disease suggest that a malignant state may be transferred between lineages. Because B-cell leukemia is associated with mutations in transcription factors of importance for stable preservation of lineage identity, we here investigated the potential lineage plasticity of leukemic cells. We report that primary pro-B leukemia cells from mice carrying heterozygous mutations in either or both the $P a x 5$ and $E b f 1$ genes, commonly mutated in human leukemia, can be converted into $T$ lineage leukemia cells. Even though the conversion process involved global changes in gene expression and lineage-restricted epigenetic reconfiguration, the malignant phenotype of the cells was preserved, enabling them to expand as $\mathrm{T}$ lineage leukemia cells in vivo. Furthermore, while the transformed pro-B cells displayed plasticity toward myeloid lineages, the converted cells failed to cause myeloid leukemia after transplantation. These data provide evidence that a malignant phenotype can be transferred between hematopoietic lineages. This has important implications for modern cancer medicine because lineage targeted treatment of leukemia patients can be predicted to provoke the emergence of phenotypically altered subclones, causing clinical relapse.

[Keywords: B-ALL; lineage conversion; transcription factors]

Supplemental material is available for this article.

Received June 14, 2016; revised version accepted October 31, 2016.

Leukemia commonly involves a single blood cell lineage with expansion of lymphoid progenitor cells (B- or T-cell lymphoblastic leukemia) or myeloid progenitors (myeloid leukemia) (Jennings and Foon 1997; Craig and Foon 2008). The involvement of a single lineage of cells is well in line with the idea that leukemia is a monoclonal disease initiated in a lineage-restricted progenitor. However, even though this would appear to be generally applicable, a fraction of the hematopoietic malignancies appears to involve multiple lineages (Jennings and Foon 1997; Craig and Foon 2008; Manola 2013). These malignancies, denoted as acute leukemia of ambiguous lineage (ALAL), can be manifested as either bilineal leukemia, involving several lineages, or biphenotypic disease, with expansion of cells displaying combined expression of normally lineage-restricted surface markers (Jennings and Foon 1997; Craig and Foon 2008; Manola 2013). Additionally, rather dramatic phenotypic changes with preserved cytogenetic features have been reported from patients experiencing

Corresponding author: mikael.sigvardsson@liu.se Article published online ahead of print. Article and publication date are online at http://www.genesdev.org/cgi/doi/10.1101/gad.285536.116. relapse of disease (Dorantes-Acosta and Pelayo 2012). This is especially notable after treatment of pediatric B lineage acute lymphoblastic leukemia (B-ALL) using genetically manipulated $\mathrm{T}$ lymphocytes (chimeric antigen receptor $\mathrm{T}$ [CAR-T] cells) targeting CD19-positive cells because 13 out of 20 children experiencing relapse did so with CD19- leukemia cells (Gardner et al. 2016; Park et al. 2016). Even though the phenotypic changes could be explained by malignant transformation of multipotent progenitors, this could also be a consequence of genetic alterations causing lineage instability in committed progenitors.

Stable B lymphocyte identity depends on a network of transcription factors (Somasundaram et al. 2015), including PAX5, EBF1, and IKZF1 (IKAROS), all of which are crucial for stable B lineage commitment (Mikkola et al. 2002; Cobaleda et al. 2007; Reynaud et al. 2008; Nechanitzky

(C) 2016 Somasundaram et al. This article is distributed exclusively by Cold Spring Harbor Laboratory Press for the first six months after the full-issue publication date (see http://genesdev.cshlp.org/site/misc/ terms.xhtml). After six months, it is available under a Creative Commons License (Attribution-NonCommercial 4.0 International), as described at http://creativecommons.org/licenses/by-nc/4.0/. 
et al. 2013; Ungerback et al. 2015). Interestingly, mutations of transcription factors involved in the regulation of cell identity are prominent in B-ALL, where heterozygote inactivation of $P A X 5, E B F 1$, or IKZF1 is detected in a substantial fraction of the patients (Kuiper et al. 2007; Mullighan et al. 2007, 2008).

In order to explore whether disruption of a transcription factor network in leukemia cells causes lineage plasticity to generate biphenotypic or bilineal leukemia, we decided to explore the ability of mouse B-ALL cells carrying disruptions in fate-determining regulatory networks (Prasad et al. 2015) to adopt alternative cell fates. This revealed that either constitutive activation of Notch1 signaling or externally mediated Notch activation resulted in lineage switch of B-ALL cells to T lineage cells displaying a pronounced developmental block and expansion capacity in vitro and in vivo. The B lineage leukemia cells could be converted into myeloid cells; however, these displayed a mature phenotype with pronounced ability to respond to LPS and severely reduced ability to expand and generate malignant disease in vivo. This reveals that secondary genetic alterations as well as environmental signals may impact the phenotype of B-ALL cells and that the malignant state, including the block of differentiation, can be transferred between lymphoid lineages.

\section{Results}

Constitutive activation of the Notch signaling

pathway in pro-B leukemia cells causes lineage conversion and expansion of CD19-negative leukemia cells in vivo

In order to explore whether a leukemic pro-B cell can be converted into a T-lineage cell, we decided to explore this ability in a mouse model carrying a combined heterozygous loss of the Pax5 and Ebf1 genes (Ungerback et al. 2015). The majority of these mice develops monoclonal or oligoclonal B-lineage leukemias before the age of 30 wk (Supplemental Fig. S1; Prasad et al. 2015) that, after transplantation, display a stable phenotype with expansion of leukemic pro-B cells in the bone marrow (BM) and spleens of the recipients (Prasad et al. 2015). In order to explore whether constitutive activation of Notch signaling, a feature commonly detected in human T-ALL (Weng et al. 2004; Lobry et al. 2011), would change the phenotype of the leukemia cells, we transduced four independently derived primary pro-B leukemia samples from lymph nodes (LNs) collected from leukemic $\mathrm{Pax}^{+/-}$ Ebf1 $1^{+-}(T H)$ mice (\#377, \#436, \#619, and \#655) with a retrovirus encoding a constitutively active Notch 1 protein (ICN1) (Pui et al. 1999). Cultivation of the transduced tumor cells on OP9 stroma cells induced Thy1.2 expression on three of the tumors transduced with the GFP control vector (Fig. 1A,B). In contrast, the ICN1-expressing cells down-regulated the expression of CD19 (Fig. 1A,B), yielding between $50 \%$ and $95 \%$ Thy $1.2^{+} \mathrm{CD} 19^{-}$cells. Exploring CD3 expression on the surface of Thy1.2 $2^{+}$cells revealed a low frequency of $\mathrm{CD}^{+}$cells. Quantitative PCR (qPCR) analysis of CD19- Thy $1.2^{+}$cells revealed down-regulation of the B-cell-restricted Igll1 gene, while the levels of the T-lineage-associated Cd3e and Lck genes were increased as compared with what we observed in the $\mathrm{CD} 9^{+}$cells (Fig. 1C). RNA sequencing (RNA-seq) experiments using two tumors (\#377 and \#619) and in vitro differentiated $\mathrm{B}$ and $\mathrm{T}$ cells explored with unsupervised cluster analysis revealed that, while the control virus transduced cells clustered with the normal CD19 ${ }^{+}$cells, the cells transduced with the ICN1-expressing virus clustered with the T-lineage cells (Fig. 1D). Identifying differentially expressed genes (Supplemental Table S1-S4) linked ICN1 expression to down-regulation of B-lineagerestricted genes, including Pax5, Cd79a, Cd79 $\beta$, Igll1, and Cd19, and up-regulation of genes associated with Tlineage development such as Gata3, Tcf7, and Cd3e. Performing a gene ontology (GO) term analysis of the genes with increased expression in the ICN1 transduced cells revealed a significant enrichment of genes linked to $\mathrm{T}$ cell differentiation and function (Fig. 1E; Supplemental Tables S3, S7), while the GO terms identified for the down-regulated genes included B-cell activation (GO: 0042113) and the B-cell receptor signaling pathway (GO: 005853) (Supplemental Table S7-S8). qPCR analysis of genomic DNA from ICN1 transduced tumor cells allowed for detection of TCR $\beta$ DJ rearrangement at a level comparable with that of in vitro differentiated normal $\mathrm{T}$-lineage cells (Fig. 1F), while TCR $\beta$ VDJ recombination was not observed in vitro. To verify that the generated $\mathrm{T}$-lineage cells were derived from the transformed pro-B-cell tumor, we explored VDJ recombination events in the immunoglobulin heavy chain (IgH) locus in $\mathrm{CD}_{1}{ }^{-}$Thy $1.2^{+}$and $\mathrm{CD} 19^{+}$cells generated from tumor \#377 (Fig. 1G). This revealed that the CD19- ${ }^{-}$Thy $1.2^{+}$cells carried a VDJ rearranged $\mathrm{IgH}$ similar to what we observed in the $\mathrm{CD} 19^{+}$ cells, supporting that the cells represent the same leukemic clone.

Even though it is possible to identify childhood B-ALL leukemia that, similar to our mouse model, contains combined heterozygous deletion of $P A X 5$ and EBF1 (Mullighan et al. 2007; Prasad et al. 2015), it is rare in comparison with single-heterozygous mutations in either the $P A X 5$ or EBF1 gene (Mullighan et al. 2007; Prasad et al. 2015). While we rarely found leukemia development in single-heterozygote mice, a few cases were found among our animals, creating the possibility of exploring whether leukemia cells from single-heterozygote mice display T-lineage plasticity. To this end, we infected two pro-B-cell tumors from $\mathrm{Pax}^{+/-}$mice and two from Ebf1 ${ }^{+/-}$animals with ICN1 and explored the development of CD19-Thy $1.2^{+}$cells (Supplemental Table S9). This revealed that one of the Ebf1 $1^{+/-}$and one of the $\mathrm{Pax} 5^{+/-}$tumors gave a robust conversion of cells into a CD19- Thy $1.2^{+}$phenotype, while few $\mathrm{CD}^{+}$cells were generated. Hence, activation of Notch signaling in B-cell tumors carrying disruption in critical lineage-specifying transcription factors results in a switch of the tumor phenotype.

In order to investigate whether ICN1-expressing tumor cells could expand to generate a leukemic disease in vivo, we transplanted ICN1 transduced LN cells from three individual leukemic mice (\#278, \#327, and \#377) and pMIG- 
GFP transduced LN cells from two individual mice (\#327 and \#377) into wild-type C57BL6 mice. After 3-4 wk, several of the transplanted mice displayed disease symptoms, including a partial paralysis also observed after transplantation of primary tumors (Prasad et al. 2015). Analysis of the spleens from the mice transplanted with cells transduced with a GFP control virus revealed a peripheral expansion of $\mathrm{CD}_{19}{ }^{+}$cells (Fig. 2A,B), well in line with the previously observed stable phenotype of these tumors (Prasad et al. 2015). Analyzing the expansion of the ICN1 transduced tumor cells in the spleen revealed that, even though all of the animals displayed some expansion of CD19 ${ }^{+}$cells (Fig. 2A,B), all three tumors generated Thy $1.2^{+} \mathrm{CD} 19^{-}$cells, of which only a fraction were $\mathrm{CD}^{+}$, suggesting that the cells are developmentally blocked. Analyzing the cellular composition of the thymus supported the notion that developmentally blocked CD19 ${ }^{-}$Thy $1.2^{+}$cells expand after transplantation. However, in contrast to what we observed in the spleen, the thymus contained a fraction of $\mathrm{CD} 19^{-}$Thy $1.2^{+}$cells generated from the GFP control transduced B-lineage

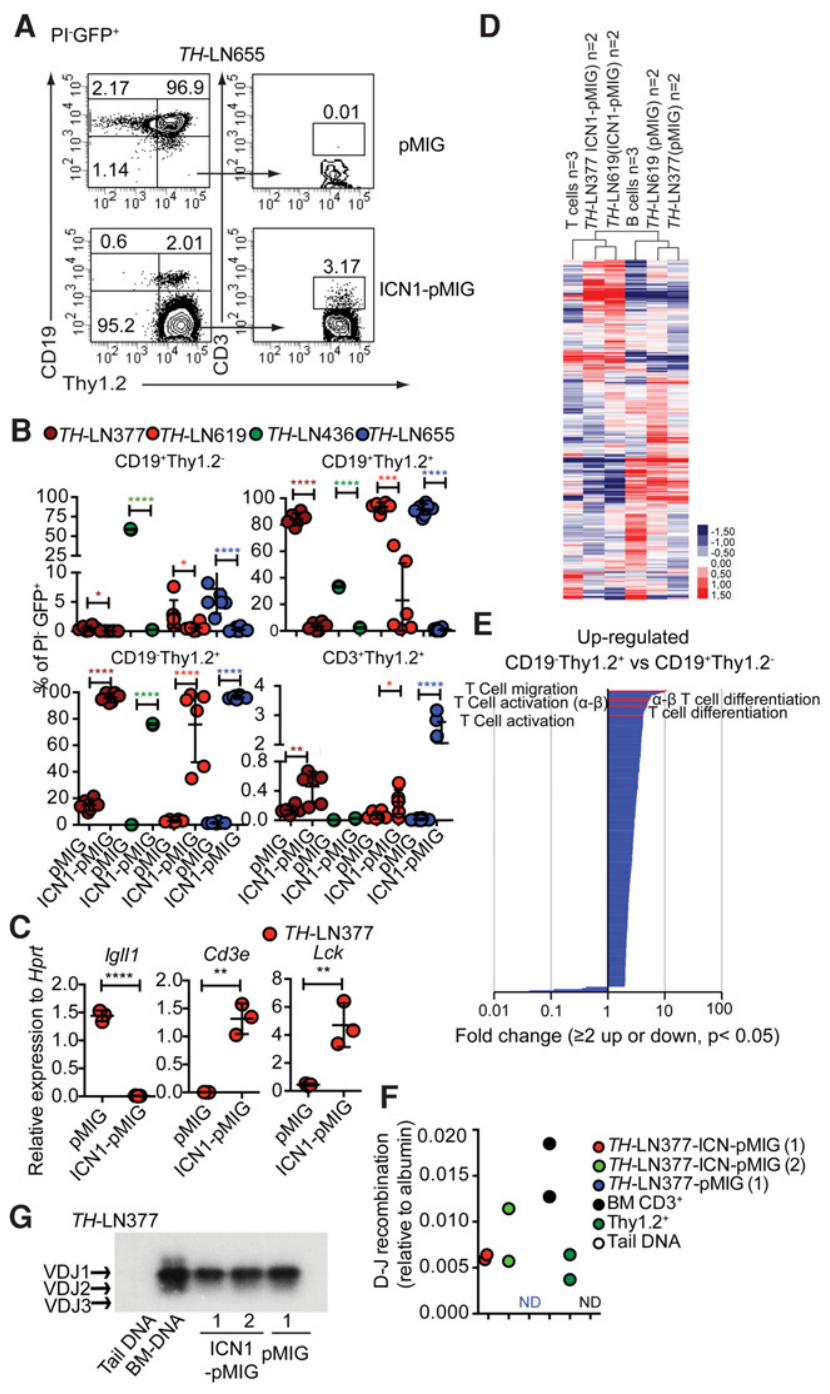

tumor cells. qPCR analysis of sorted pMIG-GFP transduced $\mathrm{CD}_{19}{ }^{+}$cells as well as ICN1-pMIG transduced CD $19^{-}$Thy $1.2^{+}$cells from the thymi of the transplanted mice revealed that, while the $\mathrm{CD} 19^{+}$populations expressed Igll1, only the CD19 ${ }^{-}$Thy $1.2^{+}$cells expressed the T-lineage-associated $\mathrm{Cd} 3 e$ and Gata3 and high levels of $L c k$ (Fig. 2C). qPCR analysis using genomic DNA detected TCR $\beta$ DJ as well as low levels of TCR $\beta$ VDJ recombination in the ICN1 transduced cells (Fig. 2D). The B-cell origin of the cells was verified in one of the tumors by $\mathrm{IgH}$ VDJ recombination analysis, revealing a dominant expansion of a leukemic cell carrying a $\mathrm{VDJ}_{1}$ recombination event in the $\mathrm{CD}_{1} 9^{+}$as well as the CD19 ${ }^{-}$Thy $1.2^{+}$ populations (Fig. 2E). Hence, the lineage identity of tumor cells can be influenced by the local microenvironment to generate two phenotypically distinct but clonal tumors in the host.

Figure 1. Constitutively active Notch signals in $\mathrm{Pax}^{+/-} \mathrm{Ebf1^{+/- }}$ pro-B leukemia cells cause lineage conversion from the pro-B-cell stage to the early T-cell stage in vitro. $(A)$ Representative FACS plots from in vitro differentiation of TH-LN655 with or without a constitutively active Notch1 signal. (B) Graph displaying the percentage of $\mathrm{PI}^{-} \mathrm{GFP}^{+}$events for the indicated populations generated from four TH pro-B tumors (\#377, \#436, \#619, and \#655) after $14 \mathrm{~d}$ of coculture on OP9 stroma with or without a constitutive Notch1 signal. Statistical analysis was based on unpaired Student's $t$-test. Asterisks in the same color as the tumor depicted in the figure indicate significance. $\left.\left(^{*}\right) P<0.05 ;\left({ }^{* *}\right) P<0.01 ;{ }^{* * *}\right)$ $P<0.001$; $\left.{ }^{* * * *}\right) P<0.0001$. (C) qPCR analysis after $14 \mathrm{~d}$ of OP9 coculturing of cells transduced with either ICN1-pMIG or pMIG. Each dot represents one well from cell cultures analyzed in triplicate qPCR reactions. Statistical analysis was performed using unpaired Student's $t$-test. $\left({ }^{* *}\right) P<0.01 ;\left({ }^{* * * *}\right) P<0.0001$. $(D)$ Heat map displaying an unsupervised hierarchical clustering analysis of RNA-seq data from primary in vitro differentiated $\mathrm{T}$ cells $(\mathrm{T}$ cells) or B cells (B cells) as well as CD19+Thy1.2 $2^{+}$cells (pMIG transduced cells) and CD19- Thy $1.2^{+}$(ICN1-pMIG transduced) tumor cells $14 \mathrm{~d}$ after transduction. Data were normalized to 10 million mapped reads in log scale and were visualized by Java TreeView following hierarchical clustering in cluster 3 (log transform, centering genes on mean, average linkage cluster). (E) GO enrichment analysis of genes up-regulated twofold or more in ICN1 transduced cells with a statistic significance $(P<$ $0.05)$ in $D$. Significantly $(P<0.05)$ enriched (twofold or more) or impoverished $(\leq 0.5$-fold) annotations from a biological process are shown. The $X$-axis indicates the value of fold enrichment. Some terms associated with T-cell development are highlighted. $(F)$ qPCR data detecting the presence of TCR $\beta$ DJ recombination events in ICN1 or control transduced tumor cells. Primary sorted $\mathrm{CD}^{+}{ }^{+} \mathrm{BM}$ cells $\left(\mathrm{BM} \mathrm{CD}^{+}\right)$, Thy $1.2^{+}$in vitro differentiated T-lineage cells $\left(\right.$ Thy $\left.1.2^{+}\right)$, and mouse tail DNA were included as positive and negative controls, respectively. The data were normalized to the amplification of a genomic fragment from the albumin gene and present two experiments with duplicate qPCR reactions. $(G)$ IgH VDJ recombination was analyzed by PCR using genomic DNA from CD19 Thy $1.2^{+}$(pMIG) and CD19-Thy 1.2 (ICN1-pMIG) cells from TH-LN377. Generated PCR products were visualized by Southern blot. Wild-type mouse tail DNA and BM DNA were used as negative and positive controls, respectively. 


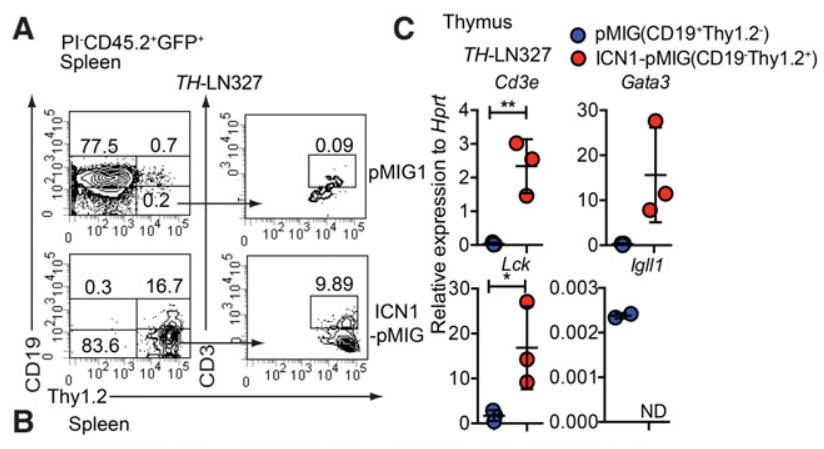

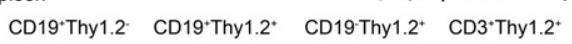

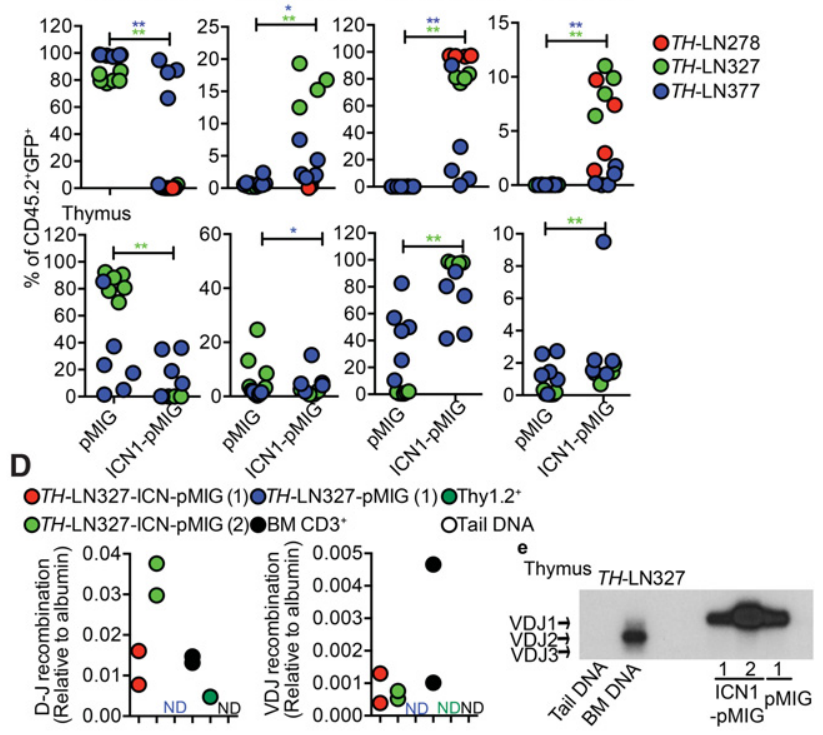

Figure 2. Constitutive activation of the Notch signaling pathway in $\mathrm{Pax}^{+/-} \mathrm{Ebf1}^{+/-}$pro-B leukemia cells causes lineage conversion and expansion of $\mathrm{CD} 19^{-}$Thy $1.2^{+}$leukemia in vivo. $(A)$ Representative FACS plot of the spleen from a CD45.1 mouse transplanted with ICN1-pMIG or pMIG transduced TH-LN327 (CD45.2) cells. The numbers represent the percentage of total $\mathrm{PI}^{-} \mathrm{CD} 45.2^{+} \mathrm{GFP}^{+}$events. (B) Percentage of the indicated cell populations (\% of $\mathrm{PI}^{-} \mathrm{CD} 45.2^{+} \mathrm{GFP}^{+}$events) in the spleens and thymi of transplanted mice. Each dot indicates one transplanted mouse, and the color code indicates one independently generated tumor. Statistical analysis was performed using Mann-Whitney $U$-test. $\left.\left(^{*}\right) P<0.05 ;{ }^{* *}\right) P<0.01$. Asterisks in the same color as the tumor depicted in the figure indicate significance. $(C)$ qPCR analysis of CD19+Thy $1.2^{+}$(pMIG) and CD19 $9^{-}$Thy $1.2^{+}$ (ICN1-pMIG) cells sorted from the thymus of a mouse transplanted with TH-LN327 cells. Statistical analysis was performed using unpaired Student's $t$-test. $\left({ }^{*}\right) P<0.05 ;\left(^{* *}\right) P<0.01$. $(D)$ qPCR data displaying TCR $\beta$ DJ and VDJ recombination events in ICN1 or control tumor cells. Primary sorted $\mathrm{CD}^{+} \mathrm{BM}$ cells $(\mathrm{BM}$ $\mathrm{CD}^{+}$), Thy $1.2^{+}$in vitro differentiated T-lineage cells (Thy $1.2^{+}$, and mouse tail DNA were included as positive and negative controls, respectively. The data were normalized to the amplification of a genomic fragment from the albumin gene and present two experiments with duplicate qPCR reactions. $(E)$ Southern blot of PCR products from VDJ recombination events in the IgH locus using genomic DNA from CD19+Thy $1.2^{+}$(pMIG) and CD19-Thy1.2 (ICN1-pMIG) cells sorted from the thymus of a mouse transplanted with $T H$-LN377. Wild-type mouse tail DNA and BM DNA were used as negative and positive controls, respectively.
External Notch signaling is sufficient to cause lineage switch of leukemic pro-B cells

To explore whether a Notch signal is sufficient to convert the lineage identity of the tumor cells, we performed in vitro cultures on either OP9 or OP9-DL1 cells, the latter expressing the Notch ligand Deltal (Schmitt and ZunigaPflucker 2002). While CD19 expression was retained when the cells were cultured on OP9, OP9-DL1 influenced the generation of $\mathrm{CD} 19^{-}$Thy $1.2^{+}$cells, with few cells displaying surface expression of CD3 (Fig. 3A; Table 1). Cultivation of three $\mathrm{Pax}^{+/-}$and two $\mathrm{Ebfi}^{+/-}$tumors under OP9-DL1 conditions for $14 \mathrm{~d}$ resulted in the development of Thy $1.2^{+} \mathrm{CD} 19^{-}$cells in two of the $\mathrm{Pax}^{+/-}$tumors (Table 1), verifying the plasticity in single Pax5 heterozygote tumor cells. In order to explore the importance of the reduced PAX5 dose in the conversion process, TH tumor cells were transduced with either a GFP control virus or a virus encoding PAX5. The cells transduced with control- and PAX5-encoding virus expanded as $\mathrm{CD} 19^{+}$cells under B-cell conditions (Supplemental Fig. S3). However, while incubation of the transduced cells on OP9-DL1 cells allowed the control transduced cells to expand as $\mathrm{CD} 19^{-}$Thy $1.2^{+}$cells, the tumor cells with ectopic expression of PAX5 were unable to grow and generate $\mathrm{CD} 19^{-}$cells. Hence, a high level of PAX5 expression is incompatible with T-lineage switch in the tumor cells.

qPCR analysis of populations from OP9- and OP9-DL1cultured cells from both transheterozygous and singleheterozygous tumor cells revealed increased expression of T-cell genes and reduced expression of B-lineage genes in association with loss of CD19 expression (Fig. 3B; Supplemental Fig. S2). The formation of $\mathrm{CD}^{+}$cells was limited; however, the major fraction of the cells coexpressed KIT (Supplemental Fig. S4) and CD25 (Fig. 3C,D), while fewer cells expressed CD44. Hence, even though high KIT expression normally is limited to the DN1 and DN2 stages, the low expression of CD44 indicates that the major part of the cells resides in the DN2-DN4 stage (Rothenberg 2014; Yui and Rothenberg 2014). Even though it would appear as if the converted cells cannot be assigned to any one specific DN stage, the lack of CD3 expression and high expression of KIT support the idea that the cells display an early block of differentiation. Hence, environmental signals may impact the lineage identity of a leukemic cell.

The efficiency of the conversion process was explored by limiting dilution experiments, revealing that the cloning frequency of the B-cell tumors on OP9-DL1 cells was about one-fifth of that on OP9 cells, with the absolute majority of the clones generated on the OP9-DL1 cells containing CD19-Thy $1.2^{+}$cells (Supplemental Fig. S5). To explore the stability of the process, we incubated tumor cells on OP9-DL1 cells for $10 \mathrm{~d}$, after which CD19+Thy $1.2^{+}$and CD19-Thy $1.2^{+}$were reseeded on either OP9 or OP9-DL1 cells (Fig. 3E). After an additional $10 \mathrm{~d}$ of culture, the cellular content was analyzed by FACS, revealing that, while the CD19 $9^{+}$Thy $1.2^{+}$cells were able to generate $\mathrm{CD} 19^{+}$cells, the $\mathrm{CD} 19^{-}$Thy $1.2^{+}$population generated only $\mathrm{CD} 19^{-}$cells 

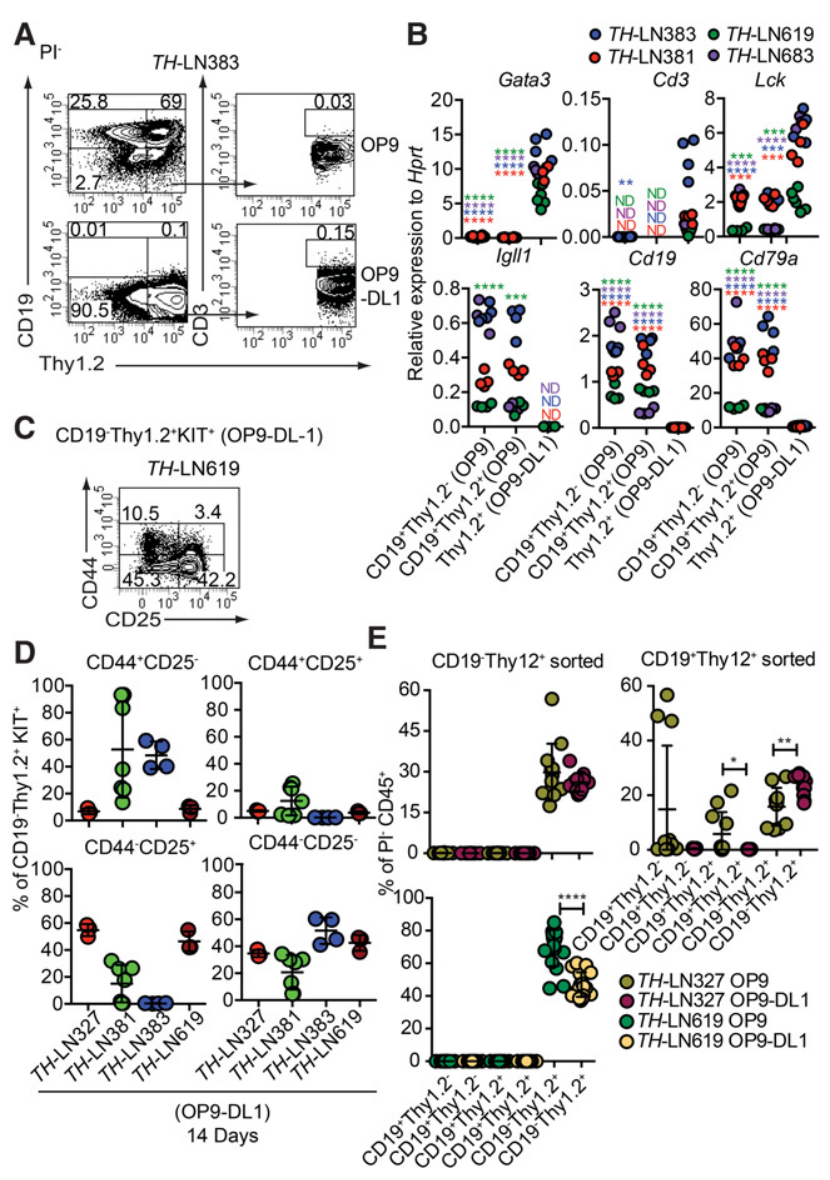

Figure 3. Extracellular Notch signals are sufficient to cause lineage switch of leukemic pro-B cells to T-lineage cells. (A) Representative FACS plots from TH-LN cultured with OP9 or OP9DL1 for $14 \mathrm{~d}$. The percentages were calculated from total $\mathrm{PI}^{-}$ events. $(B)$ qPCR analysis from $T H$ tumor cells cocultured with OP9 (CD19 ${ }^{+}$cells) or OP9-DL1 (CD19-Thy1.2 ${ }^{+}$cells) for 14 d. Each dot indicates a biological replicate analyzed by triplicate qPCR reactions, and the color of the dot indicates one independently generated tumor. Statistical analysis was performed using unpaired Student's $t$-test. Asterisks in the same color as the tumor depicted in the figure indicates significance. $\left(^{* *}\right) P<0.01$; $(* * *) P<0.001 ;(* * * *) P<0.0001$. (C) Representative FACS plot of TH-LN619 cells after $14 \mathrm{~d}$ of in vitro differentiation on OP9DL1 displaying the percentage of cells (\% of live events) positive, negative, or double positive for CD44/CD25. (D) Diagrams displaying expression of CD44 and CD25 analyzed by flow cytometry in cells from four TH tumors. (Red) Tumor \#327; (green) tumor \#381; (blue) tumor \#383; (dark red) tumor \#619. The percentage of the indicated cell type was calculated from the total number of CD19 ${ }^{-}$Thy $1.2^{+} \mathrm{KIT}^{+}$events. (E) Diagrams displaying the percentage of the indicated populations out of $\mathrm{PI}^{-}$events after reseeding of either CD $19^{-}$Thy $1.2^{+}$or CD $19^{+}$Thy $1.2^{+}$cells on OP9 or OP9-DL1 cells followed by coculture for $10 \mathrm{~d}$. Each dot indicates one culture, and statistical analysis was performed using Mann-Whitney $U$-test. (*) $P<0.05$; (**) $P<0.01$; $\left(^{* * * *}\right) P<$ 0.0001 .

even under B-cell conditions. Hence, the conversion process is robust and induces a stable change of lineage identity.
Ectopic expression of C/EBP proteins results in conversion of leukemic pro- $B$ cells into monocytic cells lacking in vivo expansion potential

It has been reported that the expression of C/EBP proteins causes a phenotypic conversion of B-lineage tumor cells to generate myeloid cells (Xie et al. 2004; Bussmann et al. 2009) with reduced malignant potential (Rapino et al. 2013; McClellan et al. 2015). To explore the ability of $\mathrm{Pax}^{+/-} \mathrm{Ebf1}^{+/-}$to generate myeloid cells, we transduced normal wild-type cells as well as single $\mathrm{Pax}^{+/-}, \mathrm{Ebf1}^{+/-}$, or $\mathrm{Pax}^{+/-} \mathrm{Ebf1}^{+/-}$pro-B tumor cells with a retrovirus encoding the transcription factor C/EBP $\beta$ (Fig. 4A,B; Supplemental Fig. S6). The majority of the C/EBP $\beta$ transduced cells developed into a CD19- ${ }^{-}$state in a matter of $5 \mathrm{~d}$, and, even though we noted a transient formation of $\mathrm{CD} 19^{+} \mathrm{CD} 11 \mathrm{~b}^{+}$biphenotypic progenitors, these cells were virtually lost after $5 \mathrm{~d}$ of incubation, generating CD19-CD11 b ${ }^{+}$cells (Fig. 4A,B). May-Giemsa staining of the converted cells revealed that the absolute majority displayed a nuclear morphology of monocytes $(\mathrm{M})$ rather than that of granulocytes (Fig. 4A). IgH VDJ analysis supported their B-lineage origin (Fig. 4C), and qPCR analysis revealed a down-regulation of $I g l 11$ and up-regulation of the myeloid gene Myleo-peroxidase ( $\mathrm{Mpo}$ ) in the converted cells (Fig. $4 \mathrm{D})$. The C/EBP $\beta$ transduced cells were able to mount a response to LPS stimulation, reflected in induced expression of $I 16, I 11 \beta, I 112 p 40$, and TNFa mRNA (Fig. 4E; Supplemental Fig. S7), revealing functional features of monocytes.

In order to explore whether the $\mathrm{CD} 19^{-} \mathrm{CD} 11 \mathrm{~b}^{+}$population could cause a malignant expansion generating a myeloid leukemia in vivo, we transduced leukemic pro-B cells with either control- or C/EBP $\beta$-encoding retrovirus, cultivated the cells in vitro for $5 \mathrm{~d}$, and transplanted sorted $\mathrm{CD}_{19}{ }^{+} \mathrm{CD} 11 \mathrm{~b}^{-}$cells from the control and CD19 ${ }^{-} \mathrm{CD} 11 \mathrm{~b}^{+}$ cells from the C/EBP $\beta$-expressing cells. Three weeks to 4 wk after transplantation, the mice receiving the control transduced cells developed signs of disease with expansion of $\mathrm{GFP}^{+} \mathrm{CD} 19^{+} \mathrm{CD} 11 \mathrm{~b}^{-}$leukemic pro-B cells in the $\mathrm{BM}$ and spleens (Fig. 4F,G). GFP ${ }^{+}$cells were rare or absent in the spleens of mice transplanted with the converted $\mathrm{CD}_{19}{ }^{-} \mathrm{CD} 11 \mathrm{~b}^{+}$cells. Furthermore, the major part of the $\mathrm{GFP}^{+}$cells detected was $\mathrm{CD} 19^{+} \mathrm{CD} 11 \mathrm{~b}^{-}$(Fig. 4F,G), arguing against the converted cells being able to generate a myeloid-like leukemia in vivo.

This finding is in line with existing literature (Rapino et al. 2013; McClellan et al. 2015); however, because C/ EBP proteins may act as tumor suppressors (Pabst et al. 2001; Nerlov 2004), continued ectopic expression of C/ $\mathrm{EBP}$ proteins from the retroviral insertions might counteract the formation of myeloid leukemia. In order to explore this possibility, we took advantage of a $\mathrm{C} / \mathrm{EBPa}$ retrovirus carrying the protein fused to a tamoxifen (4-OHT)-responsive estrogen receptor (ER) protein, allowing us to modulate the nuclear localization of the protein via the addition of 4-OHT. The conversion process was totally dependent on the addition of 4-OHT to the cultures (Fig. 5A, $\mathrm{B}$, left panel), and the retraction of the drug resulted in reduced in vitro expansion of the converted CD19-CD $11 \mathrm{~b}^{+}$ cells (Fig. 5B, right panel). Exploring changes in RNA 
Table 1. Extracellular Notch signals in $\mathrm{Pax}^{+/-}$and TH pro-B leukemia cells cause lineage conversion from the pro-B-cell stage to the early-T-cell stage in vitro

\begin{tabular}{|c|c|c|c|c|}
\hline Population & Tumor & OP9 & OP9-DL1 & $P$-values \\
\hline \multirow[t]{11}{*}{${\mathrm{CD} 19^{+} \text {Thy } 1.2^{-}}^{-}$} & LN-TH327 & $6.56 \% \pm 0.30 \%(n=3)$ & $1.02 \% \pm 0.97 \%(n=4)$ & $\overline{0.0053^{\mathrm{a}}}$ \\
\hline & LN-TH381 & $4.50 \% \pm 0.48 \%(n=10)$ & $0.89 \% \pm 0.35 \%(n=11)$ & $<0.0001^{\mathrm{b}}$ \\
\hline & LN-TH383 & $20.75 \% \pm 2.89 \%(n=8)$ & $2.05 \% \pm 0.82 \%(n=8)$ & $<0.0001^{b}$ \\
\hline & LN-TH484 & $8.70 \% \pm 0.05 \%(n=4)$ & $0.17 \% \pm 0.15 \%(n=4)$ & $<0.0001^{b}$ \\
\hline & LN-TH619 & $15.13 \% \pm 1.23 \%(n=7)$ & $0.2 \% \pm 0.54 \%(n=9)$ & $<0.0001^{b}$ \\
\hline & LN-TH683 & $37.37 \% \pm 0.08 \%(n=4)$ & $0.06 \% \pm 0.0 \%(n=4)$ & $<0.0001^{\mathrm{b}}$ \\
\hline & LN-Pax $5^{+/-} 233$ & $53.79 \% \pm 2.67 \%(n=5)$ & $17.90 \% \pm 4.0 \%(n=6)$ & $<0.0001^{\mathrm{b}}$ \\
\hline & LN-Pax $5^{+/-} 369$ & $50.24 \% \pm 0.21 \%(n=3)$ & $68.25 \% \pm 7.73 \%(n=3)$ & ns \\
\hline & LN-Pax $5^{+/-} 434$ & $62.25 \% \pm 0.07 \%(n=3)$ & $\leq 0.05 \%(n=3)$ & na \\
\hline & LN-Ebf1 $1^{+/-} 294$ & $83.89 \% \pm 0.92 \%(n=3)$ & $62.11 \% \pm 0.29 \%(n=3)$ & $<0.0001^{b}$ \\
\hline & LN-Ebf1 $1^{+/-} 449$ & $25.05 \% \pm 5.10 \%(n=6)$ & $9.29 \% \pm 2.89 \%(n=5)$ & $0.0319^{\mathrm{c}}$ \\
\hline \multirow[t]{11}{*}{ CD19+Thy1.2 $2^{+}$} & LN-TH327 & $9.41 \% \pm 0.56 \%(n=3)$ & $1.21 \% \pm 0.08 \%(n=3)$ & $0.0001^{\mathrm{d}}$ \\
\hline & LN-TH381 & $50.38 \% \pm 9.53 \%(n=11)$ & $5.97 \% \pm 2.29 \%(n=11)$ & $0.0002^{\mathrm{d}}$ \\
\hline & LN-TH383 & $67.14 \% \pm 1.72 \%(n=8)$ & $9.13 \% \pm 3.5 \%(n=8)$ & $<0.0001^{\mathrm{b}}$ \\
\hline & LN-TH484 & $77.05 \% \pm 0.23 \%(n=4)$ & $0.07 \% \pm 0.05 \%(n=4)$ & $<0.0001^{\mathrm{b}}$ \\
\hline & LN-TH619 & $77.00 \% \pm 3.17 \%(n=7)$ & $8.62 \% \pm 2.67 \%(n=9)$ & $<0.0001^{b}$ \\
\hline & LN-TH683 & $57.36 \% \pm 0.20 \%(n=4)$ & $0.15 \% \pm 0.03 \%(n=4)$ & $<0.0001^{b}$ \\
\hline & LN-Pax $5^{+/-} 233$ & $46.48 \% \pm 3.10 \%(n=5)$ & $83.46 \% \pm 3.92 \%(n=6)$ & $<0.0001^{b}$ \\
\hline & LN-Pax $5^{+/-} 369$ & $0.39 \% \pm 0.01 \%(n=3)$ & $5.47 \% \pm 1.88 \%(n=3)$ & ns \\
\hline & LN-Pax $5^{+/-} 434$ & $0.60 \% \pm 0.01 \%(n=3)$ & $\leq 0.05 \%(n=3)$ & na \\
\hline & LN-Ebf1 $1^{+/-} 294$ & $1.88 \% \pm 0.11 \%(n=3)$ & $36.49 \% \pm 4.13 \%(n=3)$ & $<0.0001^{\mathrm{b}}$ \\
\hline & LN-Ebf1 $1^{+/-} 449$ & $77.84 \% \pm 4.63 \%(n=6)$ & $92.28 \% \pm 2.47 \%(n=5)$ & $0.0294^{\mathrm{c}}$ \\
\hline \multirow[t]{11}{*}{ CD19-Thy1.2 $2^{+}$} & LN-TH327 & $56.37 \% \pm 1.36 \%(n=3)$ & $95.20 \% \pm 1.50 \%(n=3)$ & $<0.0001^{\mathrm{b}}$ \\
\hline & LN-TH381 & $25.98 \% \pm 3.34 \%(n=11)$ & $79.78 \% \pm 2.90 \%(n=11)$ & $<0.0001^{b}$ \\
\hline & LN-TH383 & $6.40 \% \pm 1.6 \%(n=8)$ & $69.36 \% \pm 8.2 \%(n=8)$ & $<0.0001^{b}$ \\
\hline & LN-TH484 & $7.88 \% \pm 0.12 \%(n=4)$ & $89.17 \% \pm 3.57 \%(n=4)$ & $<0.0001^{\mathrm{b}}$ \\
\hline & LN-TH619 & $5.08 \% \pm 1.9 \%(n=7)$ & $81.03 \% \pm 2.82 \%(n=9)$ & $<0.0001^{b}$ \\
\hline & LN-TH683 & $3.52 \% \pm 0.10 \%(n=4)$ & $83.29 \% \pm 0.49 \%(n=4)$ & $<0.0001^{\mathrm{b}}$ \\
\hline & LN-Pax $5^{+/-} 233$ & $1.11 \% \pm 0.20 \%(n=5)$ & $0.27 \% \pm 0.10 \%(n=6)$ & $0.0027^{\mathrm{a}}$ \\
\hline & LN-Pax $5^{+/-} 369$ & $\leq 0.05 \%(n=3)$ & $17.16 \% \pm 7.99 \%(n=3)$ & na \\
\hline & LN-Pax $5^{+/-} 434$ & $1.51 \% \pm 0.0 \%(n=3)$ & $63.47 \% \pm 0.67 \%(n=3)$ & $<0.0001^{\mathrm{b}}$ \\
\hline & LN-Ebf1 $1^{+/-} 294$ & $\mathrm{ND}(n=3)$ & $\leq 0.05 \%(n=3)$ & na \\
\hline & LN-Ebf1 $1^{+/-} 449$ & $0.20 \% \pm 0.07 \%(n=6)$ & $0.13 \% \pm 0.03 \%(n=5)$ & ns \\
\hline \multirow{11}{*}{$\mathrm{CD}^{+}$Thy $1.2^{+}$} & LN-TH327 & $0.46 \% \pm 0.15 \%(n=3)$ & $0.06 \% \pm 0.0 \%(n=3)$ & ns \\
\hline & LN-TH381 & $0.11 \% \pm 0.0 \%(n=4)$ & $0.18 \% \pm 0.08 \%(n=11)$ & ns \\
\hline & LN-TH383 & $0.16 \% \pm 0.07 \%(n=11)$ & $0.08 \% \pm 0.03 \%(n=8)$ & ns \\
\hline & LN-TH484 & $1.53 \% \pm 0.80 \%(n=8)$ & $0.50 \% \pm 0.29 \%(n=4)$ & ns \\
\hline & LN-TH619 & $\leq 0.05 \%(n=4)$ & $0.53 \% \pm 0.16 \%(n=9)$ & na \\
\hline & LN-TH683 & $0.08 \% \pm 0.02 \%(n=7)$ & $0.09 \% \pm 0.0 \%(n=4)$ & ns \\
\hline & LN-Pax $5^{+/-} 233$ & $\leq 0.05 \%(n=5)$ & $\mathrm{ND}(n=6)$ & na \\
\hline & LN-Pax $5^{+/-} 369$ & $\mathrm{ND}(n=3)$ & $\leq 0.05 \%(n=3)$ & na \\
\hline & LN-Pax $5^{+/-} 434$ & $\leq 0.05 \%(n=3)$ & $0.5 \% \pm 0.02 \%(n=3)$ & na \\
\hline & LN-Ebf1 $1^{+/-} 294$ & ND & ND & na \\
\hline & LN-Ebf1 $1^{+/-} 449$ & $\leq 0.05 \%(n=6)$ & $\leq 0.05 \%(n=5)$ & na \\
\hline
\end{tabular}

${ }^{\mathrm{a} P}<0.01$.

${ }^{\mathrm{b}} \mathrm{P}<0.0001$.

${ }^{\mathrm{c}} P<0.05$.

${ }^{\mathrm{d}} P<0.0005$.

$\mathrm{TH}, \mathrm{Pax} 5^{+/-}$, or Ebf1 ${ }^{+/-}$pro-B cells were in vitro differentiated for $14 \mathrm{~d}$ by culturing on either OP9 or OP9-DL1 stroma cells. The percentages of $\mathrm{CD} 19^{+}$Thy $1.2^{-}, \mathrm{CD} 19^{+}$Thy $1.2^{+}, \mathrm{CD} 19^{-}$Thy $1.2^{+}$, and CD3 ${ }^{+}$Thy $1.2^{+}$(percentage of live) are indicated. All percentages were calculated from the total number of live events. Statistical analysis was performed using unpaired Student's $t$-test. (ND) nondetectable; (ns) nonsignificant; (na) not applicable (sample for which statistical analysis could not be performed).

expression patterns associated with the generation of $\mathrm{CD} 19^{-}$cells by unsupervised cluster analysis of RNAseq data from 4-OHT-treated control transduced (pMIG) cells or cells transduced with the C/EBPa-ER-expressing virus revealed that the latter clustered together with in vitro differentiated normal $\mathrm{CD} 11 \mathrm{~b}^{+}$cells rather than with the normal CD19+ cells (Fig. 5C; Supplemental Tables $\mathrm{S} 1, \mathrm{~S} 2$ ). GO analysis identified genes associated with myeloid cell function among the genes with increased expression in the C/EBPa-ER-expressing cells (Fig. 5D; Supplemental Table S5, while genes associated with Bcell differentiation (GO: 0030183) and B-cell activation 
(GO: 0042113) were found among the down-regulated genes (Supplemental Table S6).

Transplantation of pMIG transduced control cells and C/EBPa-ER converted $\mathrm{CD} 9^{-} \mathrm{CD} 11 \mathrm{~b}^{+}$cells revealed that

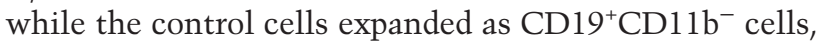
we were unable to detect $\mathrm{GFP}^{+}$cells in mice transplanted with the C/EBPa-ER converted cells (Fig. 5E). Hence, the lack of establishment of myeloid leukemia from converted leukemic pro-B cells is unlikely to be a consequence of tumor suppressor activity from the ectopically expressed C/EBP proteins but rather is a consequence of the leukemic state not being easily transferable between a lymphoid lineage and a myeloid lineage in this model system.

An easier transition of a leukemic state between lymphoid lineages could be a result of higher similarity between the mutational landscapes in lymphoid malignancies as compared with that of acute myeloid leukemia (AML). To explore this possibility, we extracted the frequency and abundance of mutated genes in human $\mathrm{T}$ ALL, B-ALL, AML, and ALAL from the COSMIC /Catalogue Of Somatic Mutations In Cancer) cancer gene census database. Analyzing these data by unsupervised cluster analysis (Fig. 5F) revealed that the AML samples

A
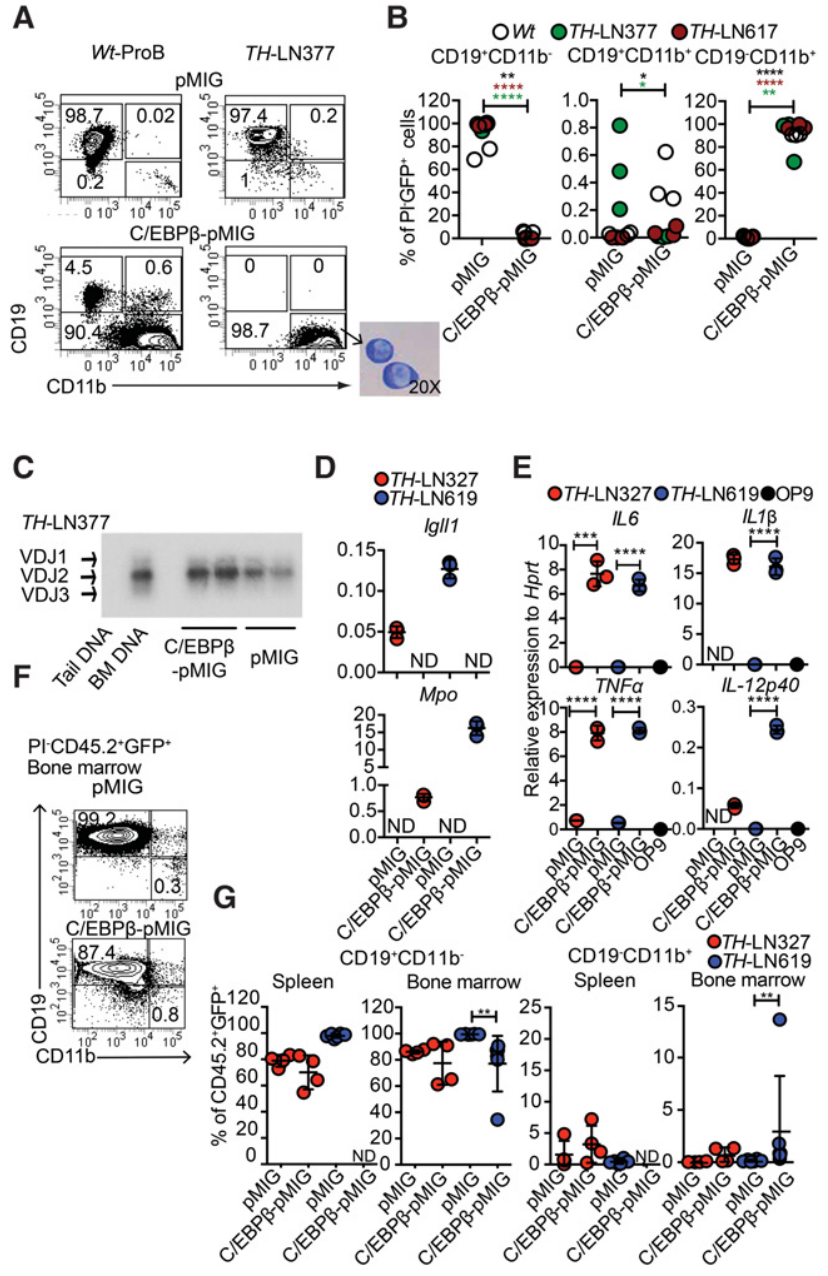

constituted a separate branch of the hierarchical tree and that the lymphoid malignancies displayed a higher degree of similarity in the mutational landscape.

The conversion of leukemic pro-B cells into T or myeloid lineages involves epigenetic changes associated with the binding of lineage-specific transcription factors

To explore whether the phenotypic alterations observed in the lineage conversion processes were reflected in changes of the epigenetic landscape, we performed ATAC-seq (assay for transposase-accessible chromatin [ATAC] combined with sequencing) analysis of $\mathrm{CD} 19^{+}$ pro-B tumor cells (tumors \#619 and \#381) converted into either T-lineage cells or macrophages as well as of in vitro differentiated nontransformed $\mathrm{B}, \mathrm{T}$, or $\mathrm{CD} 11 \mathrm{~b}^{+}$myeloid cells. Comparing the epigenetic landscape in the $\mathrm{CD} 19^{+}$ control cells and the converted $\mathrm{CD} 19^{-}$cells suggested that the conversion process has a major impact on chromatin accessibility. The transition into a myeloid state was reflected in increased accessibility at $\sim 3000$ sites and reduced accessibility at 6000 sites, and the conversion into T-lineage cells increased accessibility at 2500 sites and reduced accessibility at $\sim 16,000$ sites (Fig. 6A). The

Figure 4. $\mathrm{C} / \mathrm{EBP} \beta$ expression in leukemic pro-B cells results in lineage conversion into LPS-responsive monocytic cells but not a myeloid leukemia. (A) Representative FACS plots from in vitro differentiated $T H$-LN and wild-type pro-B cells transduced with either C/EBP $\beta$-pMIG or pMIG on OP9 coculture. The picture at the bottom of the panel displays a May-Grunwald-Giemsa staining of leukemic pro-B cells converted into CD19- $\mathrm{CD} 11 \mathrm{~b}^{+}$cells. $(B)$ Diagrams displaying the percentage of the indicated population out of total $\mathrm{GFP}^{+}$cells $5 \mathrm{~d}$ after transduction with C/EBP $\beta$ pMIG or pMIG. Each dot represents one well, and the cells used are indicated by individual color. Statistical analysis was performed using unpaired Student's $t$-test. The asterisk in the same color as the cell depicted in the figure indicates significance. $\left(^{*}\right) P<0.05$; $\left.{ }^{* *}\right) P<0.01$; $\left(^{* * * *}\right) P<0.0001$. (C) IgH VDJ recombination in genomic DNA from $\mathrm{CD}_{1}{ }^{+} \mathrm{CD} 11 \mathrm{~b}^{-}$(pMIG) and CD19-CD11b+ (C/EBPß-pMIG) of TH-LN377 analyzed by PCR followed by Southern blot. Wild-type mouse tail DNA and BM DNA were used as negative and positive controls, respectively. (D) C/EBP $\beta$-pMIG and pMIG transduced TH-LN cells were analyzed by qPCR after $5 \mathrm{~d}$ of in vitro differentiation. (ND) Nondetectable. $(E)$ qPCR analysis detecting the expression of the indicated genes in in vitro differentiated cells (as in $D$ ) after 18 $\mathrm{h}$ of treatment with $100 \mathrm{ng} / \mathrm{mL}$ LPS. Each dot represents a biological replicate analyzed by triplicate qPCR reactions, and the colors indicate independently derived tumors. (ND) Nondetectable. Statistical analysis was performed using unpaired Student's $t$ -

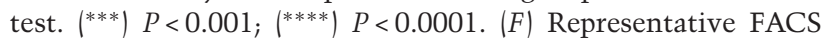
plot indicating the percentage of $\mathrm{GFP}^{+} \mathrm{CD} 45.2^{+}$cells of $\mathrm{CD} 19^{+} \mathrm{CD} 11 \mathrm{~b}^{-}$and $\mathrm{CD} 19^{-} \mathrm{CD} 11 \mathrm{~b}^{+}$in the $\mathrm{BM}$ of CD45.1 recipient mice transplanted with pMIG or C/EBP $\beta$-pMIG transduced $T H$ LN (CD45.2 donor) cells. (G) Percentages of CD19 ${ }^{+} \mathrm{CD} 11 \mathrm{~b}^{-}$and $\mathrm{CD}^{-} 9^{-} \mathrm{CD} 11 \mathrm{~b}^{+}$cells $\left(\%\right.$ of $\left.\mathrm{GFP}^{+} \mathrm{CD} 45.2^{+}\right)$from the spleens and $\mathrm{BM}$ of transplanted mice were plotted. Each dot indicates one mouse, and the color indicates tumor number as depicted in the figure. Statistical analysis was performed using Mann-Whitney $U$-test. $\left.{ }^{* *}\right) P<0.01$; (ND) nondetectable. 
major parts of the sites were located in either intergenic or intronic regions; however, T-lineage conversion involved reduced access at almost 4000 promoters. Annotation of the identified peaks to genes allowed us to match changes in accessibility to changes in gene expression patterns, revealing that a substantial part of the epigenetic changes could be linked to significant changes in mRNA levels. Over $50 \%$ of the genes up-regulated upon conversion into myeloid cells and $80 \%$ of those displaying significantly increased as well as decreased expression upon conversion into T-lineage could be annotated to changes in accessibility (Fig. 6B). Even though we could see a higher fraction of genes associated with regions of increased accessibility among the up-regulated genes and vice versa, this correlation was not absolute.

Among the promoters with reduced accessibility upon either T-lineage or myeloid conversion were several known to regulate the expression of B-cell genes, including Igl11 and Cd79a (Fig. 6C). Exploring the ATAC-seq peaks at these promoters revealed a drastic reduction in accessibility upon lineage conversion (Fig. 6C). Because EBF1 and

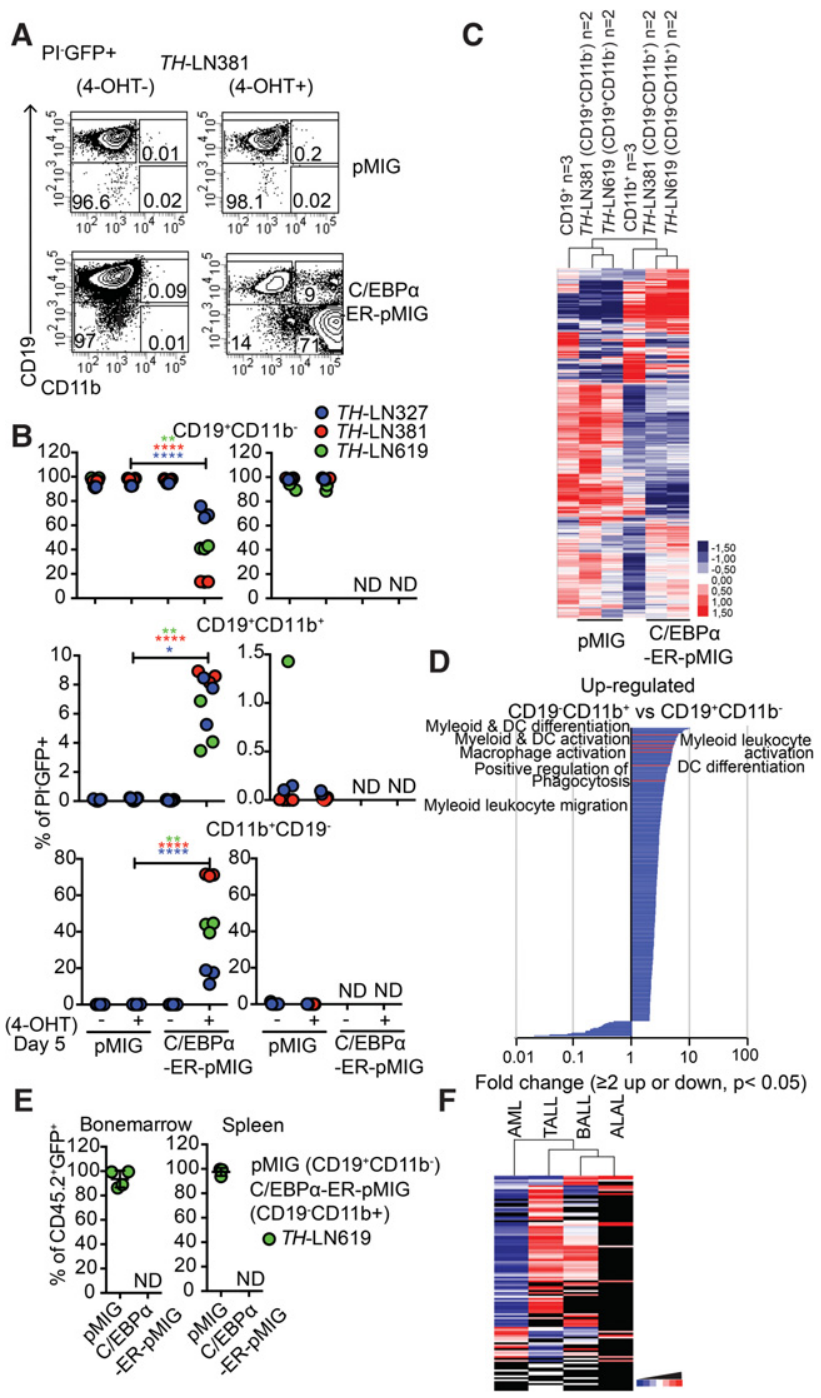

PAX5 are involved in the regulation of a large set of genes defining the early B-lineage-restricted genetic program (Zandi et al. 2008; Treiber et al. 2010; Gyory et al. 2012; Vilagos et al. 2012), we explored the overall changes in chromatin accessibility at EBF1-binding sites (GSE69227) or PAX5-binding sites (GSE38046) as determined by CHIP-seq (chromatin immunoprecipitation [ChIP] combined with high-throughput sequencing) analysis of wildtype mouse pro-B cells (Fig. 6D,E; Supplemental Table S10-S13), revealing a significant decrease in accessibility after lineage conversion.

The accessibility to the Il-1 $\beta$ promoter (Fig. 6C) rendered responsive to LPS activation in the cells converted into M-lineage cells (Fig. 4E; Supplemental Fig. S7) was

Figure 5. Reduced malignant myeloid potential in converted pro$B$ leukemia cells is not explained by sustained nuclear activity of C/EBPa proteins. (A) Representative FACS plots from in vitro differentiation of OP9 cultured TH -LN cells transduced with C/ EBPa-ER-pMIG or pMIG $5 \mathrm{~d}$ after transduction. $(B)$ Diagrams displaying the percentages of the indicated cell types out of $\mathrm{PI}^{-} \mathrm{GFP}^{+}$ cells after in vitro differentiation (as in $A$ ) of three different tumors in the presence or absence of 4-OHT. Each dot represents a well from cell culture. Statistical analysis was performed using unpaired Student's $t$-test. $\left({ }^{*}\right) P<0.05 ;\left({ }^{* *}\right) P<0.01 ;\left({ }^{* * * *}\right) P<0.0001$; (ND) nondetectable. The right panel displays the cellular content of cultures when $\mathrm{CD} 19^{+} \mathrm{CD} 11 \mathrm{~b}^{-}$from $\mathrm{pMIG}$ or $\mathrm{CD} 19^{-} \mathrm{CD} 11 \mathrm{~b}^{+}$ from C/EBPa-ER-MIG transduced cells was live-sorted after in vitro differentiation for $5 \mathrm{~d}$ on $\mathrm{OP} 9$ stroma and further cultured either with or without 4-OHT for another $5 \mathrm{~d}$. Diagrams displaying the percentages of the indicated cell types out of $\mathrm{PI}^{-} \mathrm{GFP}^{+}$cells. Each dot represents one well, and the colors indicate different tumors. (C) Heat map displaying an unsupervised hierarchical clustering analysis of RNA-seq data from primary in vitro differentiated CD $11 \mathrm{~b}^{+}$cells or B cells as well as $\mathrm{CD} 19^{+} \mathrm{CD} 11 \mathrm{~b}^{-}$ cells (pMIG transduced cells) and CD19-CD11b ${ }^{+}$(CEBPa-ERpMIG transduced) tumor cells $5 \mathrm{~d}$ after transduction. Data were normalized to 10 million mapped reads in log scale and were visualized by Java TreeView following hierarchical clustering in cluster 3 (log transform, centering genes on mean, average linkage cluster). (D) GO enrichment analysis of genes up-regulated or down-regulated twofold or more with a statistic significance. $P<$ 0.05. Significantly $(P<0.05)$ enriched (twofold or more) or impoverished $(\leq 0.5$-fold) annotations from biological process are shown. The $X$-axis indicates the value of fold enrichment. Some terms associated with myeloid cell development are highlighted. (E) FACS analysis of the spleens and $\mathrm{BM}$ from mice transplanted with $\mathrm{CD} 19^{+} \mathrm{CD} 11 \mathrm{~b}^{-}$pMIG or CD19-CD $11 \mathrm{~b}^{+} \mathrm{C} / \mathrm{EBPa}$-ER-pMIG transduced TH-LN619 cells. Percentages of CD19+CD11b- (pMIG) and $\mathrm{CD} 19^{-} \mathrm{CD} 1 \mathrm{bb}^{+}$(C/EBPa-ER-pMIG) of $\mathrm{PI}^{-} \mathrm{CD} 45.2^{-} \mathrm{GFP}^{+}$cells were plotted. Each dot indicates an individual transplanted mouse. (ND) Nondetectable. $(F)$ Heat map displaying the relationship in mutational landscapes as estimated using data from the COSMIC (Catalogue Of Somatic Mutations In Cancer) cancer gene census database-reported mutations in B-ALL $(n=1303)$, T-ALL $(n=$ 1846), acute myeloid leukemia (AML) $(n=26022)$, and ALAL ( $n$ $=52 \mathrm{l}$. Genes with mutations less common than a frequency of $0.1 \%$ were excluded from the list. The remaining list of mutations in each tumor type was subjected to hierarchical clustering using cluster 3 (log transform, center genes on mean, average linkage clustering of genes, and arrays) and was visualized in a heat map using Java TreeView. Black indicates absent value. 


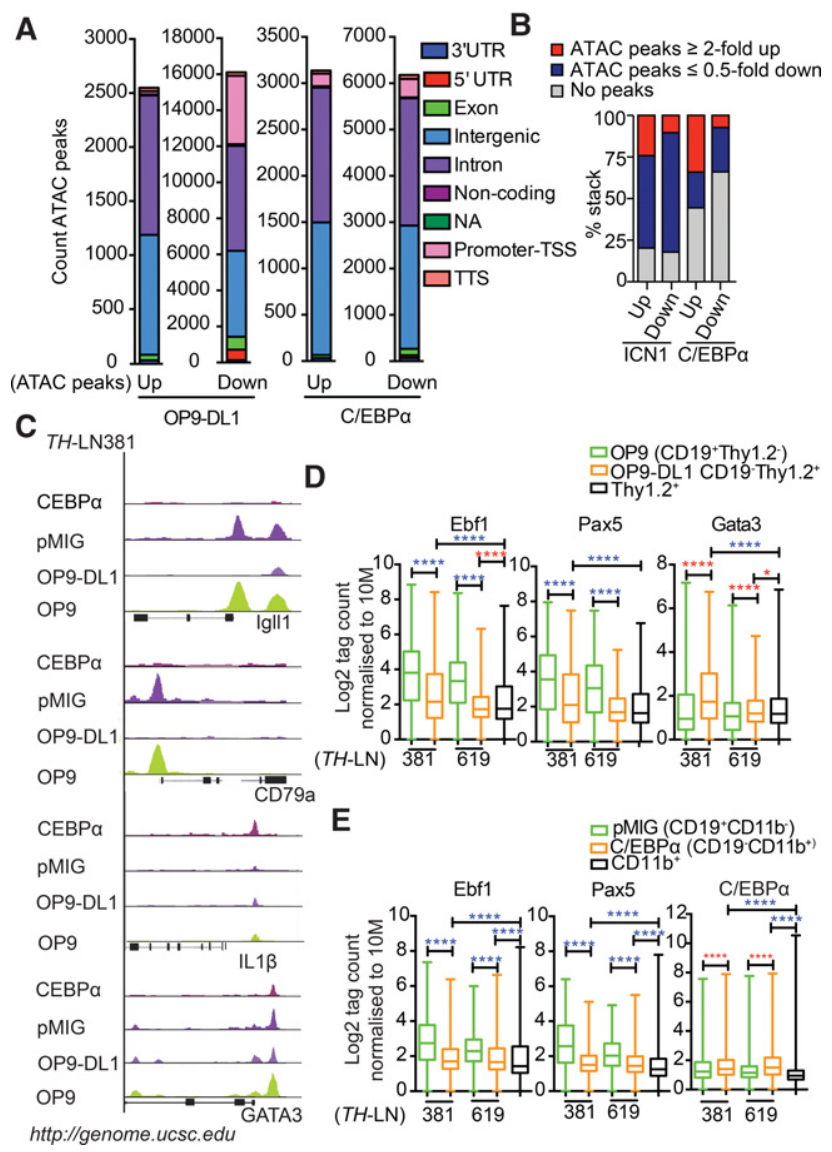

Figure 6. The conversion of leukemic pro-B cells into $\mathrm{T}$ or myeloid lineages involves epigenetic changes associated with the binding of lineage-specific transcription factors. (A) Diagrams displaying the genomic distribution of differential ATAC-seq peaks in in vitro differentiated $\mathrm{TH}$-LN cells. Sorted $\mathrm{GFP}^{+} \mathrm{CD} 19^{+} \mathrm{CD} 1 \mathrm{bb}^{-}$ and $\mathrm{GFP}^{+} \mathrm{CD} 19^{-} \mathrm{CD} 11 \mathrm{~b}^{+}$from pMIG or C/EBPa-ER-pMIG transduced cells treated with 4-OHT and $\mathrm{CD} 19^{+}$Thy $1.2^{+}$and CD $19^{-}$Thy $1.2^{+}$populations after coculturing on OP9 or OP9. DL1 stromal cells. $(B)$ Diagrams displaying the link between changes in mRNA levels (as estimated by RNA-seq analysis) and changes in chromatin accessibility (as investigated by ATAC-seq analysis). (C) Peak tracks generated from BedGraph files of ATAC tag coverage in merged duplicate samples created using HOMER and visualized on Ig111, CD79 $\alpha, I L 1 \beta$, and Gata3 genes using the University of California at Santa Cruz (UCSC) genome browser (Kent et al. 2002). (D,E) ATAC tags were annotated on peaks from ChIP-seq (chromatin immunoprecipitation [ChIP] combined with high-throughput sequencing) data retrieved from Gene Expression Omnibus (GEO) mapped to mm10 and reanalyzed for peak finding using HOMER (EBF1 [GSE69227], PAX5 [GSE38046], GATA3 [GSE31235], and C/EBPa [GSM537983]). Box plots of $\log _{2}$ tags (means from duplicates) on these peaks were quantified. Statistics was tested using one-way ANOVA with Sidak's multiple comparison test. Significant up-regulation and down-regulation are shown with red and blue asterisks, respectively; $\left(^{*}\right) P<0.05 ;\left(^{* * * *}\right) P<0.0001$.

selectively increased in the M-converted cells, and the accessibility to C/EBPa-binding sites (GSM537983) (Heinz et al. 2010) revealed increased accessibility in the $\mathrm{CD}_{11 \mathrm{~b}^{+}}$as compared with the original B cells (Fig. $6 \mathrm{E})$. Accessibility of the Gata3 promoter was decreased in the M-converted cells but was high in the T-converted cells (Fig. 6C). However, accessibility in the original tumor cells indicated that this gene is epigenetically available in B-lineage progenitors. Matching ATAC-seq data to ChIP-seq data of GATA3 binding in FLDN2b T-cell progenitors (GSE31235) (Zhang et al. 2012b) revealed a significantly increased epigenetic accessibility in the T-cell as compared with the original B-cell tumors (Fig. 6D). Hence, the conversion of pro-B tumor cells into other lineages involves changes in the epigenetic landscape.

In order to explore the progression of the conversion process, we followed the formation of $\mathrm{CD}^{-} 9^{-}$cells from Ebf1 ${ }^{+/-} \mathrm{Pax}^{+/-}$B-lineage tumor cells. Both the T-lineage and myeloid conversion processes generated intermediate states with combined expression of CD19 and Thy1.2 or CD11b (Fig. 7A,D). The presence of these cells was most prominent after 6 and $2 \mathrm{~d}$, respectively, indicating that they represent a transient cellular state. Analyzing RNAseq data from these intermediate stages by unsupervised hierarchical cluster analysis suggested that their gene expression pattern displayed a higher overall similarity to that of $\mathrm{CD} 19^{+} \mathrm{B}$-cell progenitors than the fully converted CD19 ${ }^{-}$cells (Fig. 7B,E). However, exploring accessibility at EBF1- and PAX5-binding sites suggested a reduced accessibility already in the biphenotypic cells (Fig. 7C,F). This was accompanied by increased accessibility at $\mathrm{C} /$ EBPa sites in the $\mathrm{CD} 19^{+} \mathrm{CD} 11 \mathrm{~b}^{+}$cells and GATA3-binding sites in $\mathrm{CD} 19^{+}$Thy $1.2^{+}$cells. The accessibility at TCF7 (TCF1) sites was not increased before the cells reached a CD $19^{-}$Thy $1.2^{+}$stage. Hence, even though we could observe minor changes in chromatin accessibility when comparing normal nontransformed wild-type B-lineage cells with their normal or transformed Ebf1 ${ }^{+/-} \mathrm{Pax} 5^{+/-}$ counterparts (Supplemental Fig. S8), the lineage conversion process is reflected in additional major changes of the epigenetic landscape.

\section{Discussion}

We report here that leukemic pro-B cells carrying a disruption in regulatory networks controlling lineage identity display plasticity in response to either secondary genetic events or signals in the microenvironment. The change in lineage features involves genetic reprogramming and alterations in the epigenetic landscape, arguing that the observed processes are a result of genuine lineage conversion. It has been reported that fluctuations in transcription factor dose in MYC-induced B-cell lymphoma results in phenotypic changes involving down-regulation of B-cell markers and induced expression of myeloid markers such as CD11b and F4/80 (Yu et al. 2003). Upon transplantation of the converted cells, they generated mainly B-lineage lymphoma, suggesting that the observed phenotype was a transient cellular state (Yu et al. 2003). Even though we observed a similar phenomena transplanting B-cell leukemia cells converted to M-lineage cells, we observed an 
apparent delay in the expansion of leukemia cells (Figs. 4G, 5E) more in line with data suggesting that conversion of the B-lineage cells to myeloid lineages reduces the malignancy of the cells (Rapino et al. 2013; McClellan et al. 2015) in these experimental settings.

In leukemia patients, it is more common to find ALAL with shared B and myeloid characteristics (Jennings and Foon 1997; Craig and Foon 2008; Manola 2013), and the dose of PAX5 has also been suggested to be involved in the formation of biphenotypic leukemia, which is characterized by a combined expression of B-lineage and myeloid lineage markers (Simmons et al. 2012). Even though this would be well in line with the role for PAX5 in silencing the myeloid program in B-cell progenitors (Nutt et al. 1999; Tagoh et al. 2006), we observed only a transient formation of biphenotypic cells from the $\mathrm{Pax}^{+/-} \mathrm{Ebf1}^{+/-}$pro$\mathrm{B}$ tumor cells (Figs. 4A,B, 5A,B, 7D), indicating that reduced dose as a consequence of loss of one Pax5 allele is not sufficient to generate myeloid plasticity of biphenotypic cells.

It is interesting to note that B leukemia cells converted into macrophages not only silenced the B-lineage program

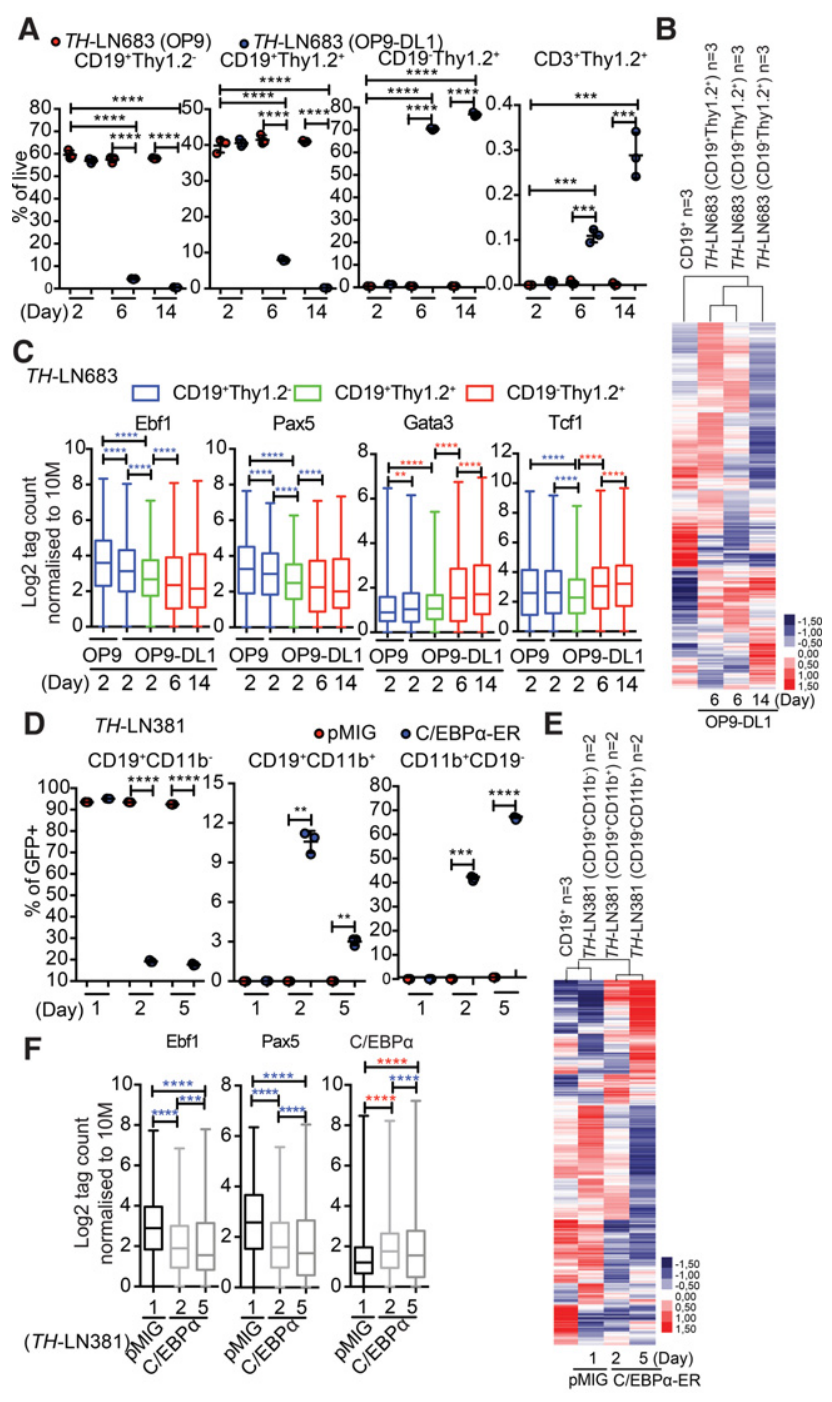

but also developed an ability to mount a robust response to LPS. This would indicate that the cells had gained at least some degree of functional maturation. This was in contrast to what we observed for the B-lineage leukemia cells converted into T-lineage cells. Even though these cells down-regulated the B-lineage program, the cells appeared unable to proceed in the differentiation pathway to generate $\mathrm{CD}^{+}$cells. Despite the fact that the surface phenotype of the converted cells was not completely compatible with any single defined normal differentiation stage and was rather heterogeneous, the lack of CD3 on the surface in combination with expression of KIT and CD25 on the majority of cells suggests that they were arrested in the DN2 stage (Rothenberg 2014; Yui and Rothenberg 2014). However, the cells did express low or undetectable levels of CD44, a marker normally expressed on DN2 cells. Even though this would be compatible with the phenotype of DN2b cells (Rothenberg 2014; Yui and Rothenberg 2014), the generated cells could not easily

Figure 7. The conversion of B-ALL cells into T or myeloid lineages proceeds through a transient biphenotypic state. $(A)$ Graph displaying the percentage $\left(\%\right.$ of $\left.\mathrm{PI}^{-} \mathrm{GFP}^{+}\right)$of the indicated cells generated from a TH pro-B tumor (\#683) after 2, 6, or $14 \mathrm{~d}$ of coculture on OP9 or OP9-DL1 stroma. Statistical analysis was performed using unpaired Student's $t$-test. $\left(^{* * *}\right) P<0.001$; (***) $P<^{* *}$ 0.0001 . (B) Heat map displaying an unsupervised hierarchical clustering analysis of RNA-seq data from primary in vitro differentiated B-cells, CD19+Thy $1.2^{+}$cells generated by cultivation of a $\mathrm{TH}$ pro-B tumor (\#683) on OP9-DL1 cells for $6 \mathrm{~d}$, and CD19-Thy1.2 $2^{+}$ cells generated after 6 or $14 \mathrm{~d}$ of incubation. Data were normalized to 10 million mapped reads in log scale and were visualized by Java TreeView following hierarchical clustering in cluster 3 (log transform, centering genes on mean, average linkage cluster). (C) Box plots displaying the relative chromatin accessibility at EBF1-, PAX5-, GATA3-, or TCF7-binding sites as assayed by ATAC-seq analysis of the indicated cell types after 2, 6, and $14 \mathrm{~d}$ of incubation. ATAC tags were annotated on peaks from ChIP-seq data retrieved from GEO mapped to mm10 and reanalyzed for peak finding using HOMER (EBF1 [GSE69227], PAX5 [GSE38046], GATA3 [GSE31235], and TCF7 [TCF1] [GSE46662]). Box plots of $\log _{2}$ tags (means from duplicates) on these peaks were quantified. Statistics were tested using one-way ANOVA with Sidak's multiple comparison test. Significant up-regulation and down-regulation are shown with red and blue asterisks, respectively. $\left.{ }^{* *}\right) P<$ $\left.\left.0.01 ;{ }^{* * *}\right) P<0.001 ;{ }^{* * * *}\right) P<0.0001$. (D) Graph displaying the percentage $\left(\%\right.$ of $\left.\mathrm{PI}^{-} \mathrm{GFP}^{+}\right)$of $\mathrm{CD} 19^{+} \mathrm{CD} 11 \mathrm{~b}^{-}, \mathrm{CD} 19^{+} \mathrm{CD} 11 \mathrm{~b}^{+}$, and $\mathrm{CD}_{19}{ }^{-} \mathrm{CD} 11 \mathrm{~b}^{+}$cells generated from a TH pro-B tumor (\#683) transduced with either control GFP virus or a virus encoding CEBPa-ER 1, 2, or $5 \mathrm{~d}$ after the addition of 4-OHT. Statistical analysis was performed using unpaired Student's $t$-test. $\left(^{* * *}\right) P<0.001$; $(* * * *) P<0.0001$. (E) Heat map displaying an unsupervised hierarchical clustering analysis of RNA-seq data from primary in vitro differentiated $\mathrm{B}$ cells and $\mathrm{CD} 19^{+} \mathrm{CD} 11 \mathrm{~b}^{-}, \mathrm{CD} 19^{+} \mathrm{CD} 11 \mathrm{~b}^{+}$, and $\mathrm{CD} 19^{-} \mathrm{CD} 11 \mathrm{~b}^{+}$cells generated as in $D$ and analyzed as in $C .(F)$ Box plots displaying the relative chromatin accessibility at EBF1-binding, PAX5-binding, or CEBPa-binding (GSM537983) sites as assayed by ATAC-seq analysis of $\mathrm{CD}_{1} 9^{+} \mathrm{CD} 11 \mathrm{~b}^{-}$, $\mathrm{CD}_{19}{ }^{+} \mathrm{CD} 11 \mathrm{~b}^{+}$, and $\mathrm{CD} 19^{-} \mathrm{CD} 11 \mathrm{~b}^{+}$generated as in $D$. ATAC tags were annotated on peaks from ChIP-seq data retrieved from GEO EBF1 (GSE69227), PAX5 (GSE38046), and C/EBPa (GSM537983) and were analyzed as in $C$. 
be assigned to any single normal stage of development. In any case, the relatively small amounts of $\mathrm{CD}^{+}$cells generated from the converted leukemia cells in vivo were in sharp contrast to the massive generation of $\mathrm{CD}^{+}$cells after transplantation of nontransformed $\mathrm{Pax}^{+/-} \mathrm{Ebf1^{+/- }}$ pro-B cells into Rag-1-deficient recipients (Ungerback et al. 2015). The difference in differentiation capacity between the converted $\mathrm{T}$ and $\mathrm{M}$ cells could also be reflected in their ability to generate a malignant expansion in the transplanted hosts. Even though care always should be taken in the interpretation of negative results, the inability of the M-converted cells to expand in vivo was in sharp contrast to the massive expansion of CD19- Thy $1.2^{+}$cells that we observed in the T-lineage-converted cells. The peripheral expansion of these immature T-lineage cells largely resembled what would be observed in a progenitor T-cell leukemia, suggesting that the leukemic state can be inherited from the $\mathrm{B}$ lineage to the $\mathrm{T}$ lineage. This would be in line with the finding that several of the genes and pathways, including IL-7 signaling, found modulated in human B-ALL are also targeted in T-ALL (Mullighan et al. 2009; Collins-Underwood and Mullighan 2010; Zhang et al. 2011, 2012a; Roberts et al. 2012).

While our data provide evidence that a leukemic state can be transferred between lymphoid lineages, it is difficult to estimate whether and, if so, how frequently lineage conversion processes are present in human leukemia. Monosomy 5 or deletion of $5 q[-5 / \operatorname{del}(5 q)]$, harboring the EBF1 gene (Milatovich et al. 1994), is found in both children and adults with the $\mathrm{B}+\mathrm{T}$ or $\mathrm{M}+\mathrm{T}$ immunophenotype (Manola 2013). Exploring the copy number status of PAX5 and EBF1 in a set of human T-ALL cell lines or primary leukemia samples (Supplemental Fig. S9) revealed that nine out of 17 cell lines and eight out of 67 primary TALL samples displayed loss of one copy of either or both of the genes. However, the deletions observed in the TALL involves large regions of the chromosome, while those detected in B-ALL often are smaller and more focused to the EBF1 or PAX5 genes (Mullighan et al. 2007). Furthermore, out of 118 human T-cell leukemias, $22 \%$ displayed recombination events in the $\mathrm{IgH}$ loci (Szczepanski et al. 1999). The majority of these events $(61 \%)$ was monoallelic recombination events, but biallelic DJ as well as some rare VDJ recombination events could also be detected. Even though IgH recombination, especially the earliest event involving DJ recombination, can be detected also in a fraction of the normal $\mathrm{T}$ cells, and the genetic loss of PAX5 and EBF1 is part of larger deletions, this supports a close relationship between lymphoid leukemias as well as the possibility of transfer between states in human disease.

The finding that B-cell tumor-derived T-lineage cells can be detected in the thymi of transplanted mice (Fig. 2B), while such cells are not detected in the BM or spleens, should be considered in light of the fact that leukemia treatment is progressing from general cytotoxic treatment that targets all hematopoietic cells into more restricted drugs targeting, for instance, a lineage-specific surface marker (Jabbour et al. 2015; Maude et al. 2015). This is a most welcome development, since it drastically reduces the side effects of the treatment; however, in a scenario in which a B-ALL has generated a small fraction of leukemic cells of another lineage, these may escape treatment to cause recurrent disease with a different phenotype. This may be an underlying explanation for the observation that a large fraction of patients experiences relapse with CD19- leukemia after treatment with CAR cells targeting CD19 on the B-ALL cell surface (Park et al. 2016). This problem is just beginning to be explored, and, in the few cases described, the relapses appear to involve the expansion of myeloid cells in one of the cases with clear relation to the original B-ALL (Gardner et al. 2016). Even though conversion into myeloid malignancies is not fully in line with our observations, the finding that the AML-like disease develops rapidly (Gardner et al. 2016) indicates that this is the consequence of expansion of existing lineage-converted subclones, well in line with our idea that a tumor clone may not be fully restricted to one lineage.

In all, we report here on the plastic nature of primary Blineage leukemia cells and show that it is possible to transfer a leukemic state between lymphoid lineages. Even though it is difficult to estimate how much this plasticity may impact human leukemia, it is becoming increasingly clear that the same regulatory pathways that regulate lineage identity are also involved in malignant transformation. Hence, we may need to reconsider our thinking about leukemia as a disease with a defined and fixed lineage.

\section{Materials and methods}

\section{Animal models}

Pax5 ${ }^{+/-}$(Urbánek et al. 1994) or Ebf1 ${ }^{+/-}$(Lin and Grosschedl 1995) cells were all on a C57BL/6 (CD45.2) background, whereas the control animals used in transplantation were on C57BL/6 (CD45.1). Pax5 $5^{+-}$and $\mathrm{Ebf1}^{+/-}$mice were crossed to generate transheterozygotes for $\mathrm{Pax}^{+/-} \mathrm{Ebf1^{+/- }}$. Animal procedures were performed with consent from the local ethics committee at Linköping University (Linköping, Sweden).

\section{Cell culture}

Normal lineage-negative Sca $1^{+} \mathrm{Kit}^{+}$cells or $\mathrm{LN}$ pro-B cells $\left(\mathrm{Lin}^{-}\right.$ $\mathrm{CD} 11 \mathrm{~b}$, Gr1, Ter119, and CD11c) NK1.1 ${ }^{-} \mathrm{IgM}^{-} \mathrm{CD} 3^{-} \mathrm{CD} 19^{+} \mathrm{CD} 3^{+}$ were sorted and expanded in vitro by coculture on OP9 or OP9. DL1 stroma cells (Schmitt and Zuniga-Pflucker 2002) using OptiMEM supplemented with $10 \%$ heat-inactivated fetal calf serum, $25 \mathrm{mM}$ HEPES, $50 \mu \mathrm{g} / \mathrm{mL}$ gentamicin, $50 \mu \mathrm{M} \beta$-mercaptoethanol, $10 \mathrm{ng} / \mathrm{mL}$ KIT ligand, $10 \mathrm{ng} / \mathrm{mL}$ Fms-like tyrosine kinase 3 ligand (FLT3L), and $10 \mathrm{ng} / \mathrm{mL}$ interleukin-7. Differentiation and transduction experiments were performed as detailed in the Supplemental Material.

\section{FACS staining}

FACS analysis was performed as in Ungerback et al. (2015). For details about antibodies and methods, see the Supplemental Material. 


\section{RNA-seq and data analysis}

Total RNA was isolated from control CD19 ${ }^{+}$LN cells (pMIG), converted $\mathrm{CD} 1 \mathrm{~b}^{+}$cells (C/EBPa-ER-pMIG), Thy1.2 $2^{+}$cells (ICN1-pMIG), and cells cultured on OP9 or OP9-DL1, and libraries were constructed using NuGEN's Ovation Ultralow library systems (NuGEN Technologies) and subsequently subjected to 76 cycles of NextSeq500 sequencing (Illumina). Each biological sample was processed and sequenced in duplicate or triplicate. For analysis of RNA-seq experiments, the reads were aligned to mouse reference genome (mm10/GRCm38) and analyzed using the HOMER platform. For details about sequencing and analysis, see the Supplemental Material. Gene lists (twofold up-regulated or down-regulated in converted cells, with a statistical significance $P<0.05$ ) from RNA-seq experiments were uploaded to Panther Overrepresentation Test (release 2016/7/15; http ://geneontology.org), and enrichment analyses were run with the GO database (released on September 24, 2016). Mus musculus genes from the database $(22,322$ genes) were used as references.

\section{PCR and RT-PCR}

qPCR analysis of sorted cells was performed as described previously (Mansson et al. 2008) using Assays-on-Demand probes. The TCR $\beta$ VDJ and DJ assays were adopted from Hamrouni et al. (2003), and the recombination events were quantified by real-time qPCR using FastStart Universal SYBR Green Master (ROX, Roche). Ig VDJ analyses were performed as in Schlissel et al. (1991). The obtained PCR products were further analyzed by Southern blot, and the correct products were detected by hybridization to a ${ }^{32} \mathrm{P}$-labeled internal $\mathrm{J}_{3}$ oligonucleotide. For details, see the Supplemental Material.

\section{Transplantation procedures}

Adoptive transfers were performed by tail vein injection. Nonirradiated CD45.1 animals were transplanted with 250,000 LN cells transduced with retrovirus for either ICN1-pMIG or pMIG for pro-B-to-T-cell experiments. For pro-B-to-myeloid experiments, 100,000 CD19-CD11b+ from C/EBP $\beta$-pMIG/C/EBPa-ER-pMIG cells or $\mathrm{CD} 19^{+} \mathrm{CD} 11 \mathrm{~b}^{-}$from $\mathrm{pMIG}$ transduced cells were transplanted into nonirradiated CD45.1 hosts.

\section{ATAC-seq}

Eighty-thousand cells from the cultures of $\mathrm{CD} 19^{+} \mathrm{LN}$ cells on OP9 or OP9-DL1 and control pMIG, C/EBPa-ER-pMIG, or ICN1-pMIG transduced CD19 ${ }^{+} \mathrm{LN}$ cells were washed in icecold PBS prior to ATAC-seq library preparation as described in Buenrostro et al. (2013). Libraries were single-end-sequenced on a NexSeq500. Each biological sample was processed for ATACseq and sequenced in triplicate. The data were mapped to mm10 using tag directories with reads mapped to the mitochondrial chromosome filtered out, and University of California at Santa Cruz (UCSC) BedGraph files normalized to 10 million total mapped reads were created using the HOMER platform (Heinz et al. 2010). ATAC-seq peaks were identified using findPeaks.pl in HOMER (Heinz et al. 2010). Published ChIP-seq data of EBF1-ChIP in pro-B cells (GSE69227), PAX5 (GSE38046) and GATA3-ChIP in T-cell progenitors (FLND2b; GSE31235), and TCF7 (TCF1; GSE46662) and C/EBPa-ChIP in thioglycolate-elicited macrophages (GSM537983) were retrieved from Gene Expression Omnibus (GEO) and remapped to mm10 using Bowtie2, and peaks were identified using HOMER with the -factor setting. Abundance of ATAC tags on the ChIP-seq peaks was analyzed in HOMER using the annotatePeaks command. For details, see the Supplemental Material.

\section{Mutation analysis of human tumors}

To explore the relationship in mutational landscapes, reported mutations in B-ALL, T-ALL, AML, and ALAL were extracted from the COSMIC cancer gene census database. Mutation frequency per reported tumor (AML, $n=26022$; T-ALL, $n=1846$; B-ALL, $n=1303$; and ALAL, $n=52$ ) was calculated. Genes with mutations less common than a frequency of $0.1 \%$ were excluded from the list. The mutation frequencies of the remaining genes in B-ALL, T-ALL, AML, and ALAL were subjected to hierarchical clustering using cluster 3 and were visualized in a heat map using Java TreeView. For details, see the Supplemental Material.

\section{Acknowledgments}

This work was supported by grants from the Swedish Cancer Society, the Swedish Childhood Cancer Foundation, the Swedish Research Council, including a Center grant to Hematolinne, the Knut and Alice Wallenbergs Foundation, and Linköping University. R.S., J.Å., J.U., K.O., and T.S. designed, conducted, and analyzed the experiments. H.L. and T.F. analyzed T-ALL data. M.S. designed the experiments and analyzed the data. All authors contributed to the writing of the manuscript.

\section{References}

Buenrostro JD, Giresi PG, Zaba LC, Chang HY, Greenleaf WJ. 2013. Transposition of native chromatin for fast and sensitive epigenomic profiling of open chromatin, DNA-binding proteins and nucleosome position. Nat Methods 10: 12131218.

Bussmann LH, Schubert A, Vu Manh TP, De Andres L, Desbordes SC, Parra M, Zimmermann T, Rapino F, Rodriguez-Ubreva J, Ballestar E, et al. 2009. A robust and highly efficient immune cell reprogramming system. Cell Stem Cell 5: 554-566.

Cobaleda C, Jochum W, Busslinger M. 2007. Conversion of mature B cells into $\mathrm{T}$ cells by dedifferentiation to uncommitted progenitors. Nature 449: 473-477.

Collins-Underwood JR, Mullighan CG. 2010. Genomic profiling of high-risk acute lymphoblastic leukemia. Leukemia 24: 1676-1685.

Craig FE, Foon KA. 2008. Flow cytometric immunophenotyping for hematologic neoplasms. Blood 111: 3941-3967.

Dorantes-Acosta E, Pelayo R. 2012. Lineage switching in acute leukemias: a consequence of stem cell plasticity? Bone Marrow Res 2012: 406796.

Gardner R, Wu D, Cherian S, Fang M, Hanafi LA, Finney O, Smithers H, Jensen MC, Riddell SR, Maloney DG, et al. 2016. Acquisition of a CD19-negative myeloid phenotype allows immune escape of MLL-rearranged B-ALL from CD19 CAR-T-cell therapy. Blood 127: 2406-2410.

Gyory I, Boller S, Nechanitzky R, Mandel E, Pott S, Liu E, Grosschedl R. 2012. Transcription factor Ebf1 regulates differentiation stage-specific signaling, proliferation, and survival of B cells. Genes Dev 26: 668-682.

Hamrouni A, Aublin A, Guillaume P, Maryanski JL. 2003. T cell receptor gene rearrangement lineage analysis reveals clues for the origin of highly restricted antigen-specific repertoires. I Exp Med 197: 601-614. 
Heinz S, Benner C, Spann N, Bertolino E, Lin YC, Laslo P, Cheng JX, Murre C, Singh H, Glass CK. 2010. Simple combinations of lineage-determining transcription factors prime cis-regulatory elements required for macrophage and B cell identities. Mol Cell 38: 576-589.

Jabbour E, O'Brien S, Ravandi F, Kantariian H. 2015. Monoclonal antibodies in acute lymphoblastic leukemia. Blood 125: 4010-4016.

Jennings CD, Foon KA. 1997. Recent advances in flow cytometry: application to the diagnosis of hematologic malignancy. Blood 90: 2863-2892.

Kent WJ, Sugnet CW, Furey TS, Roskin KM, Pringle TH, Zahler AM, Haussler D. 2002. The human genome browser at UCSC. Genome Res 12: 996-1006.

Kuiper RP, Schoenmakers EF, van Reijmersdal SV, Hehir-Kwa JY, van Kessel AG, van Leeuwen FN, Hoogerbrugge PM. 2007. High-resolution genomic profiling of childhood ALL reveals novel recurrent genetic lesions affecting pathways involved in lymphocyte differentiation and cell cycle progression. Leukemia 21: 1258-1266.

Lin H, Grosschedl R. 1995. Failure of B-cell differentiation in mice lacking the transcription factor EBF. Nature 376: 263-267.

Lobry C, Oh P, Aifantis I. 2011. Oncogenic and tumor suppressor functions of Notch in cancer: it's NOTCH what you think. I Exp Med 208: 1931-1935.

Manola KN. 2013. Cytogenetic abnormalities in acute leukaemia of ambiguous lineage: an overview. Br J Haematol 163: 24-39.

Mansson R, Zandi S, Anderson K, Martensson IL, Jacobsen SE, Bryder D, Sigvardsson M. 2008. B-lineage commitment prior to surface expression of B220 and CD19 on hematopoietic progenitor cells. Blood 112: 1048-1055.

Maude SL, Teachey DT, Porter DL, Grupp SA. 2015. CD19-targeted chimeric antigen receptor T-cell therapy for acute lymphoblastic leukemia. Blood 125: 4017-4023.

McClellan JS, Dove C, Gentles AJ, Ryan CE, Majeti R. 2015. Reprogramming of primary human Philadelphia chromosomepositive B cell acute lymphoblastic leukemia cells into nonleukemic macrophages. Proc Natl Acad Sci 112: 4074-4079.

Mikkola I, Heavey B, Horcher M, Busslinger M. 2002. Reversion of B cell commitment upon loss of Pax5 expression. Science 297: 110-113.

Milatovich A, Qiu RG, Grosschedl R, Francke U. 1994. Gene for a tissue-specific transcriptional activator (EBF or Olf-1), expressed in early B lymphocytes, adipocytes, and olfactory neurons, is located on human chromosome 5, band q34, and proximal mouse chromosome 11. Mamm Genome 5: 211-215.

Mullighan CG, Goorha S, Radtke I, Miller CB, Coustan-Smith E, Dalton JD, Girtman K, Mathew S, Ma J, Pounds SB, et al. 2007. Genome-wide analysis of genetic alterations in acute lymphoblastic leukaemia. Nature 446: 758-764.

Mullighan CG, Miller CB, Radtke I, Phillips LA, Dalton J, Ma J, White D, Hughes TP, Le Beau MM, Pui CH, et al. 2008. BCR-ABL1 lymphoblastic leukaemia is characterized by the deletion of Ikaros. Nature 453: 110-114.

Mullighan CG, Zhang J, Harvey RC, Collins-Underwood JR, Schulman BA, Phillips LA, Tasian SK, Loh ML, Su X, Liu W, et al. 2009. JAK mutations in high-risk childhood acute lymphoblastic leukemia. Proc Natl Acad Sci 106: 9414-9418.

Nechanitzky R, Akbas D, Scherer S, Gyory I, Hoyler T, Ramamoorthy S, Diefenbach A, Grosschedl R. 2013. Transcription factor EBF1 is essential for the maintenance of B cell identity and prevention of alternative fates in committed cells. Nat Immunol 14: 867-875.
Nerlov C. 2004. C/EBPa mutations in acute myeloid leukaemias. Nat Rev Cancer 4: 394-400.

Nutt SL, Heavey B, Rolink AG, Busslinger M. 1999. Commitment to the B-lymphoid lineage depends on the transcription factor Pax5 [see comments]. Nature 401: 556-562.

Pabst T, Mueller BU, Zhang P, Radomska HS, Narravula S, Schnittger S, Behre G, Hiddemann W, Tenen DG. 2001. Dominant-negative mutations of CEBPA, encoding CCAAT/enhancer binding protein- $\alpha(\mathrm{C} / \mathrm{EBP} \alpha)$, in acute myeloid leukemia. Nat Genet 27: 263-270.

Park JH, Geyer MB, Brentjens RJ. 2016. CD19-targeted CAR Tcell therapeutics for hematologic malignancies: interpreting clinical outcomes to date. Blood 127: 3312-3320.

Prasad MA, Ungerback J, Ahsberg J, Somasundaram R, Strid T, Larsson M, Mansson R, De Paepe A, Lilljebjorn H, Fioretos T, et al. 2015. Ebf1 heterozygosity results in increased DNA damage in pro-B cells and their synergistic transformation by Pax5 haploinsufficiency. Blood 125: 4052-4059.

Pui JC, Allman D, Xu L, DeRocco S, Karnell FG, Bakkour S, Lee JY, Kadesch T, Hardy RR, Aster JC, et al. 1999. Notch1 expression in early lymphopoiesis influences B versus $\mathrm{T}$ lineage determination. Immunity 11: 299-308.

Rapino F, Robles EF, Richter-Larrea JA, Kallin EM, Martinez-Climent JA, Graf T. 2013. C/EBPa induces highly efficient macrophage transdifferentiation of B lymphoma and leukemia cell lines and impairs their tumorigenicity. Cell Rep 3: 1153-1163.

Reynaud D, Demarco IA, Reddy KL, Schjerven H, Bertolino E, Chen Z, Smale ST, Winandy S, Singh H. 2008. Regulation of $\mathrm{B}$ cell fate commitment and immunoglobulin heavy-chain gene rearrangements by Ikaros. Nat Immunol 9: 927-936.

Roberts KG, Morin RD, Zhang J, Hirst M, Zhao Y, Su X, Chen SC, Payne-Turner D, Churchman ML, Harvey RC, et al. 2012. Genetic alterations activating kinase and cytokine receptor signaling in high-risk acute lymphoblastic leukemia. Cancer Cell 22: 153-166.

Rothenberg EV. 2014. Transcriptional control of early T and B cell developmental choices. Annu Rev Immunol 32: 283-321.

Schlissel MS, Corcoran LM, Baltimore D. 1991. Virus-transformed pre-B cells show ordered activation but not inactivation of immunoglobulin gene rearrangement and transcription. J Exp Med 1763: 711.

Schmitt TM, Zuniga-Pflucker JC. 2002. Induction of T cell development from hematopoietic progenitor cells by delta-like-1 in vitro. Immunity 17: 749-756.

Simmons S, Knoll M, Drewell C, Wolf I, Mollenkopf HJ, Bouquet C, Melchers F. 2012. Biphenotypic B-lymphoid/myeloid cells expressing low levels of Pax5: potential targets of BAL development. Blood 120: 3688-3698.

Somasundaram R, Prasad MA, Ungerback J, Sigvardsson M. 2015. Transcription factor networks in B-cell differentiation link development to acute lymphoid leukemia. Blood 126: 144-152.

Szczepanski T, Pongers-Willemse MJ, Langerak AW, Harts WA, Wijkhuijs AJ, van Wering ER, van Dongen JJ. 1999. Ig heavy chain gene rearrangements in T-cell acute lymphoblastic leukemia exhibit predominant DH6-19 and DH7-27 gene usage, can result in complete V-D-J rearrangements, and are rare in T-cell receptor $\alpha \beta$ lineage. Blood 93: 4079-4085.

Tagoh H, Ingram R, Wilson N, Salvagiotto G, Warren AJ, Clarke D, Busslinger M, Bonifer C. 2006. The mechanism of repression of the myeloid-specific c-fms gene by Pax 5 during B lineage restriction. EMBO J 25: 1070-1080.

Treiber T, Mandel EM, Pott S, Gyory I, Firner S, Liu ET, Grosschedl R. 2010. Early B cell factor 1 regulates B cell gene networks by activation, repression, and transcriptionindependent poising of chromatin. Immunity 32: 714-725. 
Ungerback J, Ahsberg J, Strid T, Somasundaram R, Sigvardsson M. 2015. Combined heterozygous loss of Ebf1 and Pax 5 allows for T-lineage conversion of B cell progenitors. J Exp Med 212: 1109-1123.

Urbánek P, Wang Z-Q, Fetka I, Wagner EF, Busslinger M. 1994. Complete block of early B cell differentiation and altered patterning of the posterior midbrain in mice lacking Pax5/BSAP. Cell 79: 901-912.

Vilagos B, Hoffmann M, Souabni A, Sun Q, Werner B, Medvedovic J, Bilic I, Minnich M, Axelsson E, Jaritz M, et al. 2012. Essential role of EBF1 in the generation and function of distinct mature B cell types. I Exp Med 209: 775-792.

Weng AP, Ferrando AA, Lee W, Morris JPt, Silverman LB, Sanchez-Irizarry C, Blacklow SC, Look AT, Aster JC. 2004. Activating mutations of $\mathrm{NOTCH} 1$ in human $\mathrm{T}$ cell acute lymphoblastic leukemia. Science 306: 269-271.

Xie H, Ye M, Feng R, Graf T. 2004. Stepwise reprogramming of B cells into macrophages. Cell 117: 663-676.

Yu D, Allman D, Goldschmidt MH, Atchison ML, Monroe JG, Thomas-Tikhonenko A. 2003. Oscillation between B-lymphoid and myeloid lineages in Myc-induced hematopoietic tu- mors following spontaneous silencing/reactivation of the EBF/Pax5 pathway. Blood 101: 1950-1955.

Yui MA, Rothenberg EV. 2014. Developmental gene networks: a triathlon on the course to T cell identity. Nat Rev Immunol 14: 529-545.

Zandi S, Mansson R, Tsapogas P, Zetterblad J, Bryder D, Sigvardsson M. 2008. EBF1 is essential for B-lineage priming and establishment of a transcription factor network in common lymphoid progenitors. J Immunol 181: 3364-3372.

Zhang J, Mullighan CG, Harvey RC, Wu G, Chen X, Edmonson M, Buetow KH, Carroll WL, Chen IM, Devidas M, et al. 2011. Key pathways are frequently mutated in high risk childhood acute lymphoblastic leukemia: a report from the Children's Oncology Group. Blood 118: 3080-3087.

Zhang J, Ding L, Holmfeldt L, Wu G, Heatley SL, Payne-Turner D, Easton J, Chen X, Wang J, Rusch M, et al. 2012a. The genetic basis of early T-cell precursor acute lymphoblastic leukaemia. Nature 481: 157-163.

Zhang JA, Mortazavi A, Williams BA, Wold BJ, Rothenberg EV. 2012b. Dynamic transformations of genome-wide epigenetic marking and transcriptional control establish $\mathrm{T}$ cell identity. Cell 149: 467-482. 


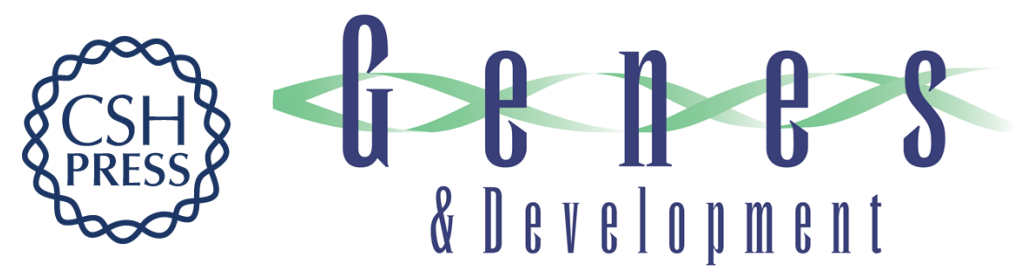

\section{Clonal conversion of B lymphoid leukemia reveals cross-lineage transfer of malignant states}

Rajesh Somasundaram, Josefine Åhsberg, Kazuki Okuyama, et al.

Genes Dev. 2016, 30: originally published online December 2, 2016

Access the most recent version at doi:10.1101/gad.285536.116

\section{Supplemental http://genesdev.cshlp.org/content/suppl/2016/12/02/gad.285536.116.DC1 Material}

References This article cites 54 articles, 25 of which can be accessed free at: http://genesdev.cshlp.org/content/30/22/2486.full.html\#ref-list-1

Creative This article is distributed exclusively by Cold Spring Harbor Laboratory Press for the first Commons six months after the full-issue publication date (see

License http://genesdev.cshlp.org/site/misc/terms.xhtml). After six months, it is available under a Creative Commons License (Attribution-NonCommercial 4.0 International), as described at http://creativecommons.org/licenses/by-nc/4.0/.

Email Alerting Receive free email alerts when new articles cite this article - sign up in the box at the top Service right corner of the article or click here.

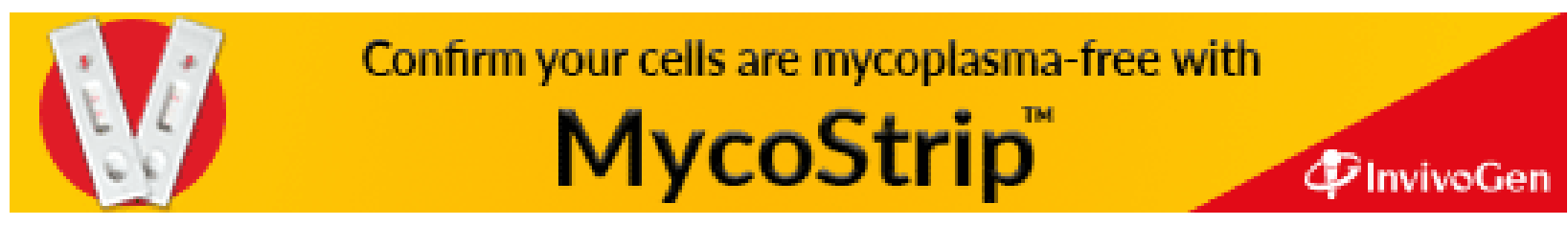

